\title{
Seasonal and Spatial Variations of Ecological Risk from Potential Toxic Elements in the Southern Littoral Zone of İzmir Inner Gulf, Turkey
}

Ebru Yesim Ozkan ( $\nabla$ ebruyesim.ozkan@ikc.edu.tr)

Izmir Katip Celebi Universitesi https://orcid.org/0000-0001-9780-6534

Şakir Fural

Kirsehir Ahi Evran Universitesi

Serkan Kükrer

Ardahan Üniversitesi: Ardahan Universitesi

Hasan Baha Büyükışık

Ege Universitesi

\section{Research Article}

Keywords: Potential toxic elements, Regional ecological risk assessment, Environmental degradation Biogenic silica, İzmir Inner Gulf, Geographical Information Systems.

Posted Date: September 20th, 2021

DOI: https://doi.org/10.21203/rs.3.rs-782841/v1

License: (9) This work is licensed under a Creative Commons Attribution 4.0 International License. Read Full License 


\title{
Seasonal and spatial variations of ecological risk from potential toxic elements in the southern littoral zone of İzmir Inner Gulf, Turkey
}

\author{
Ebru Yeşim Özkan \\ İzmir Katip Çelebi University, Faculty of Fisheries,Department of Marine Biology, Turkey \\ ebruyesim.ozkan@ikc.edu.tr \\ Şakir Fural \\ Kurşehir Ahi Evran University, Faculty of Arts and Sciences, Department of Geography, Turkey \\ Serkan Kükrer \\ Ardahan University, Faculty of Humanities and Literature, Department of Geography, Turkey \\ Hasan Baha Büyükışık \\ Ege University, Faculty of Fisheries, Department of Fisheries of Basic Sciences, Turkey
}

\begin{abstract}
This study aimed to investigate the ecological risk level of İzmir Inner Gulf. Based on the findings, port, industry, settlement and transportation activities generated $\mathrm{Mo}, \mathrm{Pb}, \mathrm{Cu}, \mathrm{Cd}, \mathrm{Zn}$ enrichment. Modified hazard quotient (MHQ) point to a high level of pollution and toxic effects for $\mathrm{Ni}$ and $\mathrm{Cr}$; significant pollution and toxic effects for $\mathrm{As}$ and $\mathrm{Hg}$, and moderate pollution and toxic effects for $\mathrm{Pb}$, $\mathrm{Zn}, \mathrm{Cu}$. According to the ecological contamination index (ECI), the inner gulf is significantly-highly polluted. Toxic risk index (TRI) and potantial ecological risk index (PERI) are also consistent with these data. According to the ECI, the inner gulf is significantly/highly polluted. TRI and the PERI are also consistent with these data. $\mathrm{Cd}$ has created a significant ecological risk in all seasons due to its high toxicity. $\mathrm{Cu}$ and $\mathrm{Pb}$ have caused moderate ecological risk in local areas near the port. A moderate potential ecological risk has been identified in all seasons throughout the inner gulf.
\end{abstract}

Keywords: Potential toxic elements, Regional ecological risk assessment, Environmental degradation Biogenic silica, İzmir Inner Gulf, Geographical Information Systems.

\section{Introduction}

The marine environment is one of the world's most valuable yet understudied areas (Williams and Antoine, 2020). This is why these habitats around the world have attracted great attention in providing basic life to people. However, due to increasing population growth, migration to coastal areas has brought great problems for aquatic environments. New difficulties and threats have emerged in marine habitats during the last few decades as a result of increased urbanization and rapid industrialization. As a result of industrial development, metals are becoming more common in the aquatic environment due to their contamination, durability and ability to be included in the food chain (Ahamad et al., 2020; Bastami et al., 2014; Xiao, 2015).

Analysis of water, sediments, and members of indigenous biota, i.e. biomonitors, can be used to determine the relative pollution of aquatic habitats by metals (Atalar et al., 2013; Phillips and Rainbow, 1993). Metals released into aquatic environments can be trapped on suspended inorganic and organic colloidal sediments before sinking to the bottom sediments, where they can be bioaccumulated and biomagnified in the food chain (Bat and Özkan,2019; Bat et al.,2015; Nowrouzi and Pourkhabbaz,2014; Schiff and Weisberg, 1999).

Sediments, which are released into the overlying water by natural and anthropogenic processes such as bioturbation and dredging, are an appropriate indication of marine ecosystem health and can represent the level of water pollution. Sediments are also significant because they may help determine the 
degree of pollution in the marine environment, protect the health of the aquatic system, and promote effective coastal management. Sediments are commonly thought of as trace element scavengers because of their propensity to transfer and store trace elements (Looi et al., 2019). Organic and inorganic matter are found in sediments in rivers, estuaries, oceans, and other water supply systems (Hasan et al., 2013; Siddiquee et al., 2006). They are linked to hydrological connectivity, vegetation features, water quality, land use, and mineral type, in addition to acting as a reservoir for contaminants such as metals (Ahamad et al., 2020; Li et al., 2013). Both natural and manmade components created or derived from the environment usually end up in sediments (Singovszka and Balintova, 2019). As a result, when metal is present, they represent a significant source of exposure for natural ecosystems as well as human activities. As a result, when metal is present, they represent a significant source of exposure for natural ecosystems as well as human activities. Metals from contaminated sediments can enter the water column as non-point sources (Algül and Beyhan, 2020; Liu, J. et al. 2017). When polluted sediments are disturbed, metals that are trapped in the sediment can be discharged into the water column, damaging water quality and aquatic life (Looi et al., 2019; Li, et al., 2012). In the food chain, these metals may be bioaccumulated and biomagnified. Metals in sediments come from either natural sources like atmospheric precipitation, ore deposits, geological weathering, storms, wind bioturbation, and wave-induced bedrock weathering, or anthropogenic sources like mining, shipping, industrial emission, smelting, fuel generation, electroplating, sludge discharge, energy transmission, dense urban areas, wastewater irrigation and agricultural activities (Sun et al., 2015; Muhammad et al., 2011, Altın et al., 2009). As a result of their toxicity, bioaccumulation, non-degradability, and vast sources, as well as their persistence in the aquatic environment, metals have piqued the interest of researchers (Gao et al., 2016).

Metals have great ecological significance due to pose significant toxicity to consumers at the top of the food chains and tendency to accumulate in both sediment and biota (Bat and Ar1c1, 2018; Bat, 2017; Bat et al., 2021). Metals absorb suspended particles and settle as sediment because they are weakly soluble in water (Bat and Özkan, 2019; Algül and Beyhan, 2020; Yang et al., 2014). Metals released from sediments into the overlying water generate secondary pollution, which can harm the aquatic system's biological status (Bat and Kurt, 2020; Varol and En, 2012; Niu et al. 2015). As a result, metals can enter the aquatic food chain, where they can accumulate in biota (Algül and Beyhan, 2020; Alrabie et al., 2019; Bat and Arc, 2018; Bat, 2017; Bat et al., 2021). Metals, unlike other contaminants, do not biodegrade and are subject to a worldwide ecological cycle in which natural waters play a key role (Bat et al., 2018; Hasan et al. 2013; Siddiquee et al., 2006). They enter aquatic systems as a result of soil and rock weathering, volcanic eruptions, and a variety of human activities involving the mining, processing, or use of metals and/or compounds containing metal contaminants (Singovszka and Balintova, 2019). Metals are found in low concentrations in natural aquatic ecosystems, typically at the nanogram to microgram per liter range, yet even at these levels, they can have significant biological consequences (Singovszka and Balintova, 2019; Atalar et al., 2013; Rainbow, 1992). However, in recent years, high metal contamination levels have become a source of growing concern, with concern of environmental pollution as a result of metal toxicity and buildup in aquatic habitats (Hasan et al., 2013). As a result, metal contamination is a difficult environmental problem that is attracting growing attention due to its potential to endanger human and ecosystem health (Looi et al., 2019; Amin et al., 2009; Tang et al., 2014). Metal pollutants present in sediments have been demonstrated to pose a risk to marine organisms in near-future ocean acidification conditions, according to studies (Williams and Antoine 2020; Roberts et al., 2013). However, the concentrations of metals in the surface horizons of the sediment alone cannot provide extensive indications about the state of contamination of sediments (Singovszka and Balintova, 2019). This type of data makes it impossible to distinguish between natural and anthropogenic enrichment. The metal 
enrichment factor (EF) and geoaccumulation indices (Igeo) are two common indexes used to determine metal concentrations of environmental significance (Singovszka and Balintova, 2019; Feng et al., 2011). These indices are used to quantify contamination levels in sediments. The amount of bioavailable metal in sediment has a significant impact on sediment quality (Singovszka and Balintova, 2019). Methods of geochemical normalization such as sediment quality guidelines (SQGs), Igeo, EF, ecological risk index (MRI), and possible ecological risk index (PERI) can be used to determine the degree of metal contamination in sediment (Ali et al., 2015; Xu et al., 2017). The EF and Igeo indexes are employed as indicators to identify and quantify the degree of elemental pollution, as well as to evaluate the intensity of anthropogenic contaminants collected in sediment (Looi et al., 2019; Barbieri, 2016). To date, numerous studies have used the EF and Igeo to assess the contribution of anthropogenic inputs of elements in sediment (Özkan, 2012; Özkan and Büyükış1k, 2012; Kaya et al., 2017; Kükrer et al., 2020; Fural et al., 2020; Fural et al., 2021).

The main objectives of the current study are: (1) to investigate the extent and degree of metal distribution and concentration in the sediment of İzmir Inner Gulf, (2) to assess the origin of these metals using EF and Igeo, and (3) to evaluate contamination of sediment using the MRI, PERI, MHQ, ECI and TRI. This study is also expected to provide the background levels of pollutants and help develop regional sediment quality guidelines.

\section{Material and method}

\subsection{Study area}

There are many gulfs with interesting hydrographic and sedimentological features, extending in the east-west direction on the coastal zone of the Anatolian peninsula facing the Aegean Sea. While some of these gulfs maintain their natural state, some are under anthropogenic pressure. İzmir Gulf is open to the anthropogenic effects of settlements, industry, transportation networks and agricultural activities. The water exchange between the Aegean Sea and İzmir Gulf, which has a semi-closed feature, is limited. This increases the likelihood of ecological risks created by potentially toxic elements discharging into the gulf. The inner gulf is a point where many streams (mainly old Gediz mouth, Bostanl1, Bayrakl1, Manda, Arap, Meles, Bornova, Polygon, Ilıca) discharge. These streams have carried urban and industrial wastes to the inner gulf for many years.

The annual average rainfall in İzmir is $711 \mathrm{~mm}$. İzmir receives $314 \mathrm{~mm}$. of precipitation in winter, $152.9 \mathrm{~mm}$. in spring, $21.4 \mathrm{~mm}$. in summer and $60.4 \mathrm{~mm}$. in autumn (MGM, 2021). Accordingly, almost half of the annual average rainfall occurs in the winter season. The wet season in İzmir is as follows: winter> spring > autumn> summer.

The characteristics of the gulf currents are determined by the complex coastline, bottom topography, islands, water exchange with the Aegean Sea, river inputs and atmospheric forces. The general current of the gulf is in the form of a cyclonic (counterclockwise) cycle that covers the entire gulf. Although this general current characteristic is always observed, it is interrupted from time to time depending on the intensity of the wind and the water exchange with the Aegean Sea and hence, cyclonicanticyclonic cycles occur. However, this interruption does is short-lived and it returns to its previous state (Beşiktepe et al., 2011). 


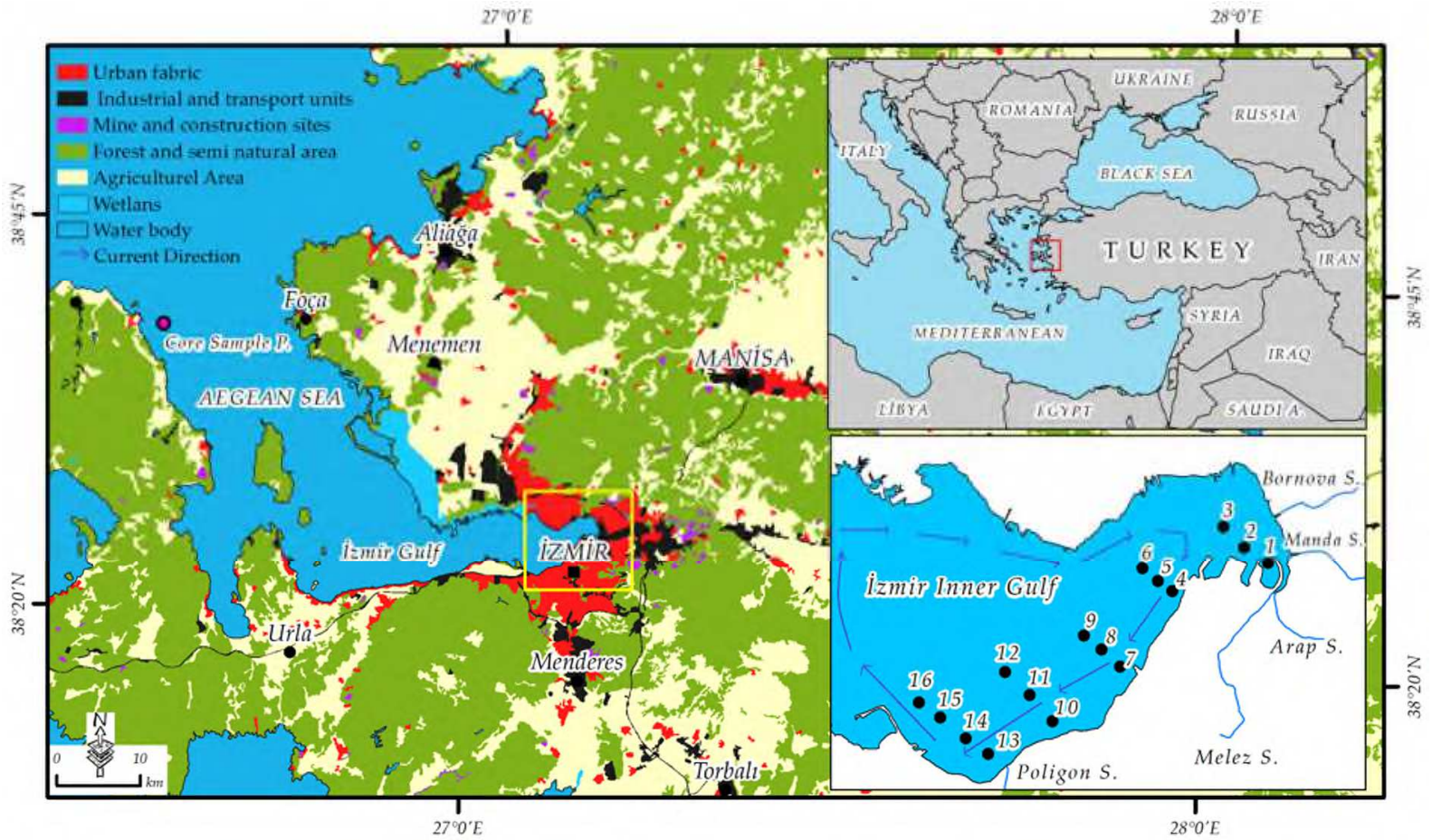

Figure 1: Location map of İzmir Inner Gulf

Major industrial activities in the region are food processing, beverage manufacturing and bottling, tanneries, oil, soap and paint production, chemical industries, paper and pulp mills, textile industries, metalworking and timber processing (Kontaş et al., 2004). Apart from these, the inner gulf was exposed to domestic wastes for many years and has gained a eutrophic character. The streams were planned to carry only rain water with the wastewater treatment plant (Grand Canal Project) which was put into operation at full capacity in 2002. This study examined the effect of the Great Canal Project on the cleansing process of the inner gulf.

İzmir Gulf is divided into three parts as inner, middle and outer gulf according to geomorphological and hydrographic features (Sunlu et al., 2012). The outer gulf is $45 \mathrm{~km}$ long in the northwest-southeast west direction and $20 \mathrm{~km}$ wide between Karaburun-Foça line. The middle and inner gulfs are $24 \mathrm{~km}$ long and $6 \mathrm{~km}$ wide in total in the east-west direction. The middle gulf, which is about $10 \mathrm{~km}$ long, is separated from the inner gulf by a very narrow sandbank of $13 \mathrm{~m}$. deep, called the Yenikale Pass. This sandbank was formed as a result of the delta advancement of the Gediz River with the Pelikan and Karşıyaka mouths in the last few centuries (Özkan et al., 2008). The study area was bordered by the mouth of Çakalburnu Dalyan in the west and Bornova Creek in the east, where the Poligon Stream, Melez Creek, Manda Creek, Arap Creek and Bornova Stream, which form the southern shores of the İzmir Inner Gulf, are discharged (Figure 1).

\subsection{Sampling and analytical methods}

Within the scope of the study, samples were taken from 16 stations selected in the southern littoral zone of the İzmir Inner Gulf for four seasons (winter, spring, summer and autumn) in 2015. Surface sediment samples were taken with a core sampler. They were then placed in plastic bags and transported to the laboratory in ice boxes. Wet samples were used for Chl-a analysis. After the sediment samples were extracted with $90 \%$ acetone, they were measured spectrophotometrically (Strickland and Parsons, 1972). Samples for total organic carbon (TOC), biogenic silica (Bsi), $\mathrm{CaCO}_{3}$ and elemental analyzes were dried in a drying-oven and pulverized by pounding in a porcelain mortar. 
TOC analyzes were performed by the Walkley-black method, which is performed by oxidation of organic matter with $\mathrm{K}_{2} \mathrm{Cr}_{2} \mathrm{O}_{7}$ (Gaudette et al., 1974). $\mathrm{CaCO}_{3}$ analyzes were carried out by the gasometric method based on the measurement of the partial pressure of the $\mathrm{CO}_{2}$ gas released from the reaction of $\mathrm{CaCO}_{3}$ with $10 \% \mathrm{HCl}$ according to (Martin, 1972). Bsi measurements were performed with the method recommended by (De Master, 1981). Elemet analyzes were performed at Bureau Veritas Laboratory (Canada) using the ICP-MS method. Standard reference material, duplicate and blind sample reading methods were used for quality control of elemental analysis. Recovery values of metal measurements vary between $83 \%$ - 114\%. Background data of a study conducted in İzmir Karaburun Gulf were used in the ecological risk index calculations. Metals background values as ppm; $\mathrm{Fe}$ (9.950), Ti (1.040) Mn (221), Cr (167), Ni (41.1), Zn (32), As (14), Co (8.7), Pb (6.35), Cu (5.8), Hg (1.67), Mo (0.3), Cd (0.05). The reliability of the metal content measurements is $95 \%$ (Özkan et al., 2017).

\subsection{Ecological risk assessment methods}

\subsubsection{Enrichment factor $(\mathrm{EF})$ and Geoaccumulation Index $\left(\mathrm{I}_{\text {geo }}\right)$}

Various indices were used for ecological and ecotoxicological evaluation of metal concentrations. Two tools were used to determine whether the detected metals were of natural origin or of anthropogenic origin. The first of these tools is the EF and is mainly found by the ratio of the current metal concentration to the background concentration. EF is calculated by the following formula:

$$
\mathrm{EF}=\frac{\left(C_{i} / C_{\text {ref }}\right)_{\text {sample }}}{\left(B_{i} / B_{\text {ref }}\right)_{\text {background }}}
$$

Here, $C_{i}$ is the metal concentration measured in sediment, $C_{r e f}$ is the concentration of the reference element selected for normalization in the sediment sample, $B_{i}$ is the regional background value of the metal and $B_{r e f}$ is the background value of the reference element selected for normalization. EF provides the option to normalize metal concentrations and uses a reference element in EF calculations that is not affected by anthropogenic inputs and chemical reactions. In this way, the grain size is normalized. It applies the same to the reference sample as well (Ahmed et al., 2018). EF results were evaluated according to Sutherland (2000): EF <2, minimal or no enrichment; EF $=2-5$, moderate enrichment; $E F=5-20$, significant enrichment; $E F=20-40$, very high enrichment and $E F>40$, extremely high enrichment.

Another index frequently used for the same purpose is $I_{\text {geo }}$ and it has been formulated below (Müller, 1969):

$$
\text { Igeo }=\log _{2} \frac{C m}{(B m * 1.5)}
$$

Here $C_{m}$ is the measured concentration of the metal and $B_{m}$ is the background value of the metal. The $\mathrm{I}_{\text {geo }}$ results were evaluated in the following manner: $\mathrm{I}_{\text {geo }} \leq 0$ uncontaminated, $0<\mathrm{I}_{\text {geo }}<1$ uncontaminated to moderately, $1<\mathrm{I}_{\text {geo }}<2$ moderately, $2<\mathrm{I}_{\text {geo }}<3$ moderately to strongly, $3<\mathrm{I}_{\text {geo }}<4$ strongly, $4<\mathrm{I}_{\text {geo }}<5$ strong to extremely, $\mathrm{I}_{\mathrm{geo}} \geq 5$ extremely. 
The potential ecological risk index proposed by (Hakanson, 1980) was used to calculate the risks that metals could create separately (MRI) and in an integrated manner (PERI). The modified approach was preferred for calculating the individual ecological risks of metals (Brady et al., 2015). Accordingly, the EF was used in the calculation instead of the contamination factor:

$$
\begin{aligned}
& \mathrm{MRI}=E f_{i} \times T r_{i} \\
& \mathrm{PERI}=\sum_{i=1}^{n} \mathrm{MRI}
\end{aligned}
$$

Here, $E f_{i}$ refers to the EF and $T r_{i}$ refers to the toxic responsibility coefficient. $T r_{i}$ values for metals are as follows: $\mathrm{Hg}=40, \mathrm{Cd}=30, \mathrm{As}=10, \mathrm{Cu}=\mathrm{Pb}=\mathrm{Ni}=\mathrm{Co}=5, \mathrm{Cr}=2, \mathrm{Mn}=\mathrm{Zn}=1$ (Hakanson, 1980; $\mathrm{Li}$ et al., 2018; Rodríguez-Espinosa et al., 2018). The results are evaluated as follows: MRI < 40 low potential ecological risk, $40 \leq$ MRI $<80$ moderate potential ecological risk, $80 \leq$ MRI $<160$ significant potential ecological risk, $160 \leq$ MRI $<320$ high potential ecological risk, and MRI $\geq 320$ very high potential ecological risk. The PERI results are evaluated as follows: PERI $<150$ low ecological risk, $150 \leq \mathrm{PERI}<300$ moderate ecological risk, $300 \leq \mathrm{PERI}<600$ significant ecological risk, PERI $\geq 600$ very high ecological risk (Hakanson, 1980).

\subsubsection{Modified hazard quotient (mHQ) and ecological contamination index (ECI)}

MRI and PERI are indices that are based on the amount of enrichment of metals in sediment. Apart from these frequently used indices, there are also indices created using the threshold values to determine the effects of metal content in sediment on aquatic biotome, such as threshold effect level (TEL), probable effect level (PEL) and severe effect level (SEL). mHQ and ECI are among these indices and are calculated in the following manner (Benson et al., 2018).

$$
\mathrm{MHQ}=\left[C_{i}\left(\frac{1}{T E L}+\frac{1}{P E L}+\frac{1}{S E L}\right)\right]^{1 / 2}
$$

Here $C_{i}$ refers to the measured metal concentration and TEL, PEL and SEL are the abbreviations for threshold effect level, probable effect level and severe effect level, respectively. TEL, PEL and SEL values are performed according to (MacDonald et al., 2000). mHQ findings are evaluated in the following manner; MHQ $<0.5$ minor, $0.5<$ MHQ $<1$ very low, $1<$ MHQ $<1.5$ low, $1.5<$ MHQ $<2$ medium, $2<$ MHQ $<2.5$ significant, $2.5<$ MHQ <3 high, $3<$ MHQ <3.5 very high, MHQ $>3.5$ extremely high/very severe.

ECI offers the opportunity to make an integrated, resource-specific assessment using a factor obtained from principal component analysis/factor analysis results (Benson et al., 2018). ECI is calculated in the following manner:

$$
\mathrm{ECI}=B_{n} \sum_{i=1}^{n} m H Q_{i}
$$

Here, $B_{n}$ is the inverse of the eigenvalue obtained from the principal component analysis for metals only with respect to multiplication. ECI findings are evaluated in the following manner: ECI $<2$ uncontaminated, $2<$ ECI $<3$ uncontaminated to slightly contaminated, $3<$ ECI $<4$ slightly to moderately contaminated, $4<$ ECI $<5$ moderately to considerably contaminated, $5<$ ECI $<6$ considerably to highly contaminated, $6<$ ECI $<7$ highly contaminated, ECI $>7$ extremely contaminated. 
TRI is another index used to determine metals ecotoxicological effects (Zhang et al., 2016). The following formula was used to determine the toxic risk index (TRI $\mathrm{T}_{\mathrm{i}}$ of each metal in the study. Here $\mathrm{C}_{i}$ refers to the measured concentration of the metal, TEL refers to "threshold effect level", and PEL refers to "probably effect level" (MacDonald et al., 1997).

$$
T R I_{i}=\sqrt{\frac{\left(\left(C_{i} / T E L\right)^{2}+\left(C_{i} / P E L\right)^{2}\right)}{2}}
$$

The TRI value which represents the toxic risk of the area is obtained by summing the TRI values calculated for each metal:

$$
T R I=\sum_{i=1}^{n} T R I_{i}
$$

The following scale is used in the interpretation of TRI values: TRI $\leq 5$ no toxic risk, $5<$ TRI $\leq 10$ low toxic risk, $10<\mathrm{TRI} \leq 15$ moderate toxic risk, $15<\mathrm{TRI} \leq 20$ considerable toxic risk, TRI $>20$ very high toxic risk.

\subsection{Spatial analysis and multivariate statistical analysis}

Spatial analyzes were performed in Arc - Map 10.7 software using the Kriging interpolation method. This method is an interpolation method that estimates the optimum values of the data at other points using the data of the nearby points, and it is calculated in the following manner:

$$
\mathrm{N}_{\mathrm{p}}=\sum_{i=1}^{n} \mathrm{Pi} \times \mathrm{Ni}
$$

In the formula; $\mathrm{N}$ refers to the number of sampling points, $\mathrm{Ni}$ refers to the geoid ondulation values of the points used in the calculation of $\mathrm{N}_{\mathrm{p}}, \mathrm{N}_{\mathrm{p}}$ refers to the ondulation value to be calculated and Pi: refers to each $\mathrm{Ni}$ value used in the calculation of $\mathrm{N}$ (ESRI, 2021).

Factor analysis, Spearman's rank correlation test and cluster analysis were performed to understand the source identification and transport processes of metals and other variables used in the study. Anova test was applied to determine seasonal differences between variables.

\section{Result and discussion}

\subsection{Spatial and seasonal change of variables}

Average concentration of metals (ppm) were listed as $\mathrm{Fe}(32.510)>\mathrm{Mn}(488)>\mathrm{Zn}(220)>\mathrm{Cr}(153)>$ $\mathrm{Ni}(86.53)>\mathrm{Pb}(79.42)>\mathrm{Cu}(64.70)>\mathrm{As}(23)>\mathrm{Co}(16.4)>\mathrm{Mo}(7.14)>\mathrm{Hg}(0.52)>\mathrm{Cd}(0.45)>\mathrm{Ti}$ (0.24). Maximum concentrations were found to be as follows: As was detected in ST 6 (33 ppm) in winter, Cd was detected in ST $10(1.32 \mathrm{ppm})$ in autumn, Cr was detected in ST 9 (256 ppm) in autumn, $\mathrm{Cu}$ was detected in ST $9(120 \mathrm{ppm})$ in autumn, Co was detected in ST 8 (22.50 ppm) in autumn, Fe was detected in ST 4 (62.200 ppm) in spring, Hg was detected in ST 10 (1.06 ppm) in autumn, Mn was detected in ST 4 (2.217 ppm) in spring, Mo was detected in ST 9 (21.70) in autumn, $\mathrm{Ni}$ was detected in ST 8 (142.40 ppm) in winter, Pb was detected in ST 2 (208.50 ppm) in autumn, Ti was detected in ST 14 (0.34) in summer and Zn was detected in ST 9 in autumn (429 ppm). According to these data, the maximum concentrations were denser in the ST 9 and ST 10 during the autumn season. As was in minimum concentration in autumn in ST 16 (9 ppm), Mn was in minimum concentration in winter in ST 14 (267 ppm), $\mathrm{Hg}$ was in minimum concentration in autumn in ST 16 
271 (0.14 ppm), Mo was in minimum concentration in spring in ST $16(1 \mathrm{ppm})$ and $\mathrm{Pb}$ was in minimum 272 concentration in autumn in ST 16 (26.70). Cd (0.05 ppm), Cr (52 ppm), Cu (23 ppm), Co (7 ppm), Fe 273 (12,200 ppm), Ni (31.90 ppm), Ti $(0.095 \mathrm{ppm})$ and $\mathrm{Zn}(67 \mathrm{ppm})$ detected at the minimum concentrations in winter in ST 1 (Figures 2 and 3). Existence of a large number of metals at minimum concentrations in winter. in ST 1 where Melez Creek, Arap Creek and Manda Creek discharge is noteworthy. It can be argued that this situation occurred due to the decrease in sedimentation rate due to the flow of stream waters discharging into the inner gulf during the rainy winter season.

According to spatial analysis data; As reached high concentrations in the mouths of Bornova Stream in winter and summer, in Poligon Stream in spring and in the mouths of Melez Creek, Manda Creek and Arap Creek in autumn. Cd and Mo were at maximum concentrations in stations close to the Poligon Stream in all seasons. $\mathrm{Cr}$ and Co were in high concentrations at stations close to the mouth of the Poligon Stream in all seasons except autumn. Cu was high at the mouth of the Poligon Stream in all seasons except summer. In summer, high values were observed around ST 4. Fe was in high concentration in the stations close to the mouth of the Poligon Stream in winter and autumn. $\mathrm{Hg}$ reached high concentrations at the stations close to the mouth of Bornova Stream in winter, Melez Creek, Arap Creek and Manda Creek in spring and at the stations close to the mouth of the Poligon Stream in autumn. Mn was in high concentration near the mouth of Bornova Stream and Poligon Stream in winter and especially at the mouth of Bornova Stream in summer. Ni was in high concentration at stations close to Bornova Stream in winter and summer and to the mouth of Poligon Stream in autumn and spring. $\mathrm{Pb}$ reached high concentrations at the mouth of the Melez Creek, Arap Creek and Manda Creek in all seasons except winter, at the stations close to the mouth of the Poligon Stream and at the mouth of Bornova Stream in winter. $\mathrm{Zn}$ was in high concentration at stations close to the mouth of the Poligon Stream in all seasons. 

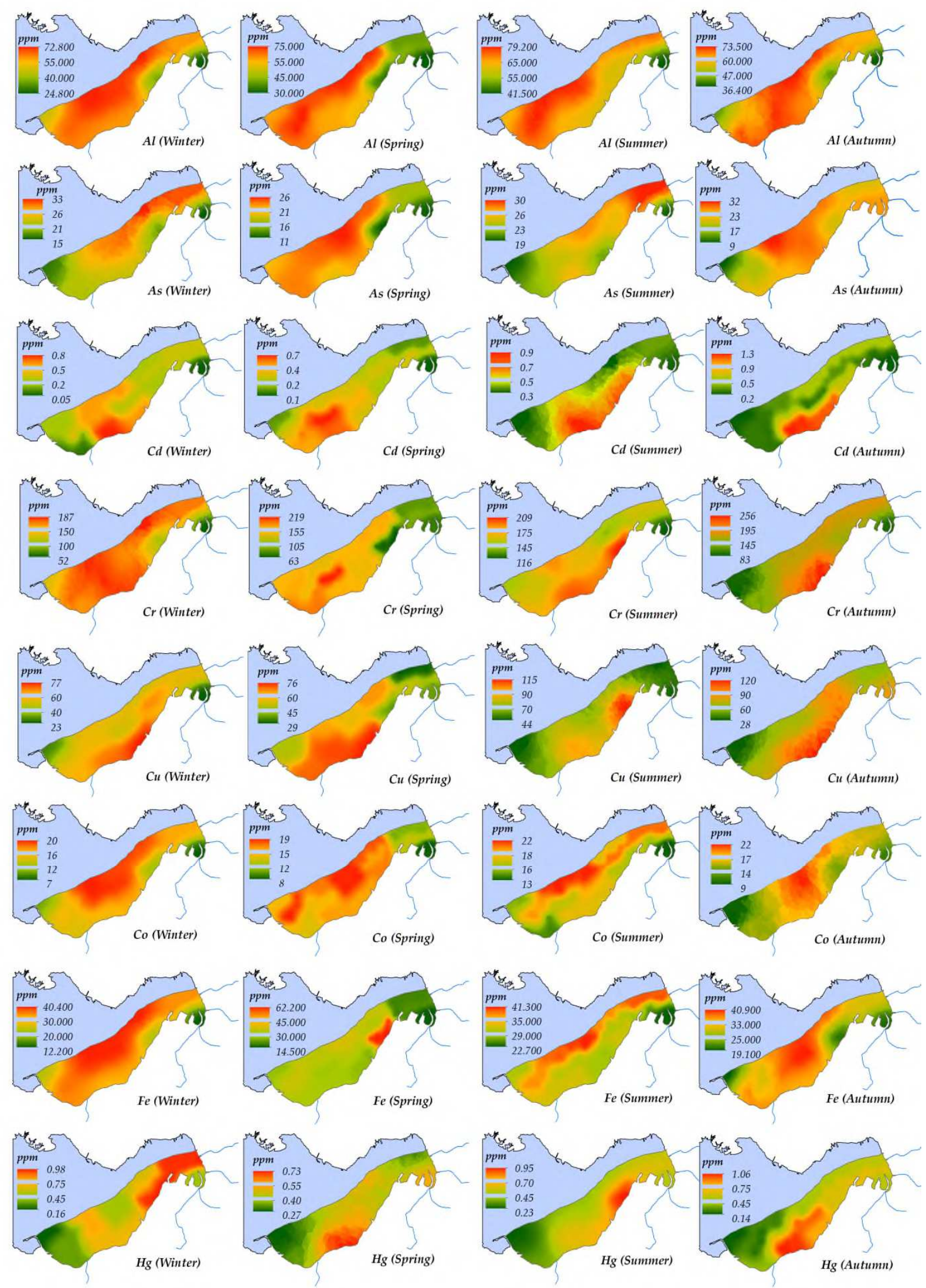

Figure 2: Spatial and seasonal change of metal concentration (part 01) 

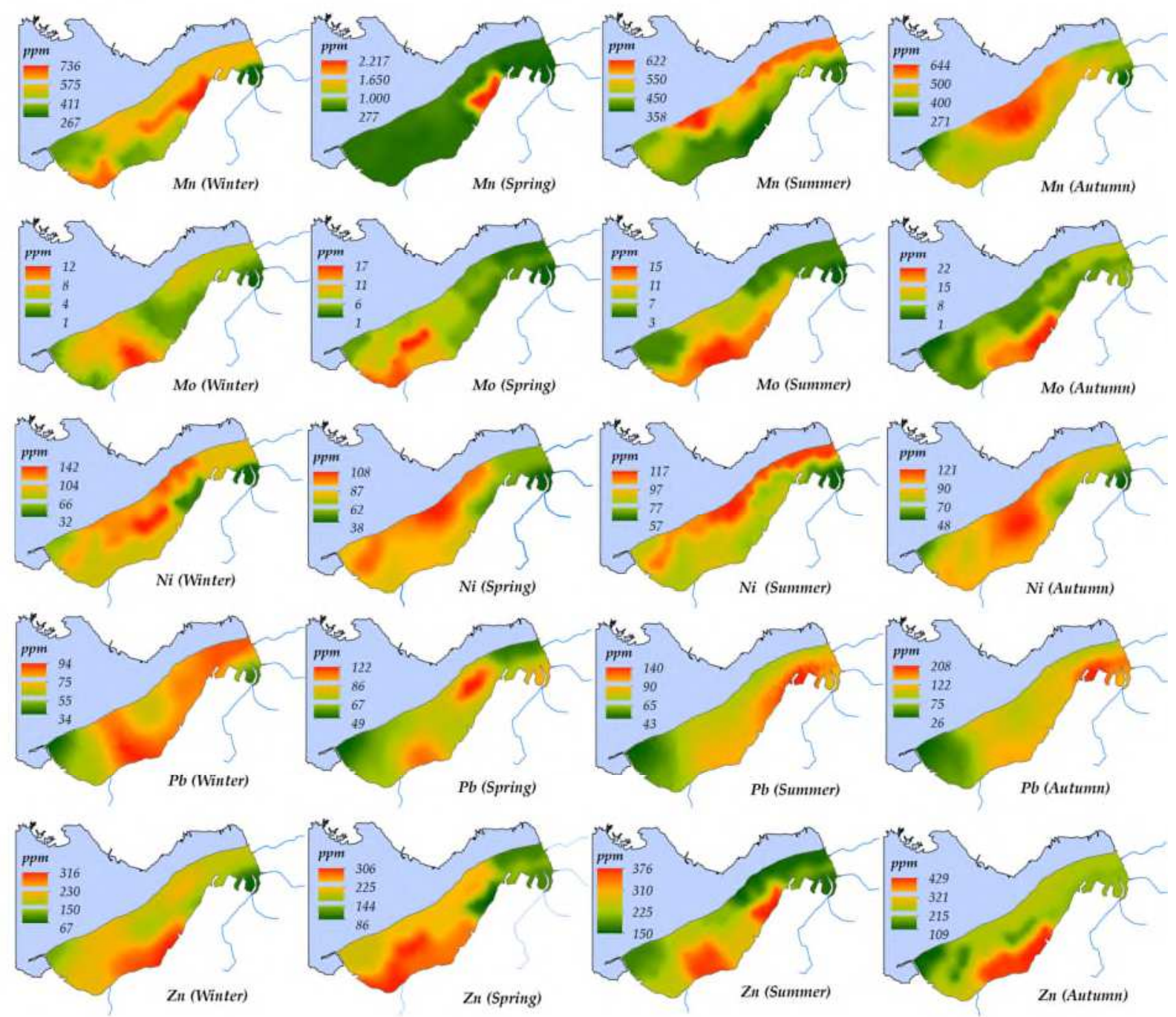

Figure 3: Spatial and seasonal change of metal concentration (part 02)

Table 1: Comparison of metal concentrations (ppm) in some gulfs in the Aegean Sea

\begin{tabular}{lccccccccccccc}
\hline Location & $\mathbf{A l}$ & $\mathbf{A s}$ & $\mathbf{C d}$ & $\mathbf{C r}$ & $\mathbf{C u}$ & $\mathbf{C o}$ & $\mathbf{F e}$ & $\mathbf{H g}$ & $\mathbf{M n}$ & $\mathbf{N i}$ & $\mathbf{P b}$ & $\mathbf{Z n}$ & Reference \\
\hline İzmir Inner G. (Turkey) & 46.900 & 23.07 & 0.45 & 114.28 & 64.49 & 16.38 & 32.500 & 0.51 & 487 & 86.64 & 79.36 & 219 & This Study \\
İzmir Inner G.(Turkey) & 19.216 & & 0.34 & 100.62 & 59.50 & & 28.383 & 0.35 & 420 & & 62.27 & 188.44 & Gülsever et al., 2019 \\
Aliağa G. (Turkey) & 60.300 & 20.60 & & 78.60 & 16.70 & & 22.000 & & 212 & 28.80 & 34.80 & 55.80 & Palas,2020 \\
Ayvalık G. (Turkey) & & 36.73 & 0.47 & 23.24 & 8.92 & 6.30 & 8.725 & & 178 & 41.42 & 14.78 & 60.73 & Tunca, et al., 2017 \\
Edremit G. (Turkey) & 35.50 & 0.23 & 29.10 & 5.05 & 7.34 & 20.819 & & 202 & 56.09 & 9.36 & 43.04 & Tunca, et al., 2017 \\
Astakos G. (Gerece) & & & 3.25 & 166 & 23 & & & & 687 & & 28 & 89 & Panagos et al., 1989 \\
Kalloni G. (Gerece) & & & 3.20 & & 48 & & & & 910 & & 96 & 103 & Varvanas, 1989 \\
\hline
\end{tabular}

The average metal concentrations of four seasons in the inner gulf of İzmir, metal concentrations of some of the gulfs in the Aegean Sea and the metal concentrations of a study conducted in 2019 in the İzmir Inner Gulf were compared. According to the findings; Al concentration was lower than Aliağa Gulf. As concentration was lower than that of Ayvalık Gulf and Edremit Gulf and higher than that of Aliağa Gulf. Cd concentration was lower than that of Edremit Gulf and higher than that of other gulfs. Cr concentration was higher than all gulfs except Astakos Gulf. Mn concentration was higher than all 
gulfs except Astakos and Kalloni Gulfs. $\mathrm{Cu}, \mathrm{Co}, \mathrm{Fe}, \mathrm{Ni}, \mathrm{Pb}, \mathrm{Zn}$ and $\mathrm{Hg}$ concentrations were higher than all comparative Gulfs. When the metal concentrations were compared with the study conducted in İzmir Inner Gulf in 2019, a decrease was observed in all values (Table 1).

TOC concentration was found to be at maximum in ST 9 (5.25\%) in winter, in ST $10(5.25 \%)$ in spring, in ST $1(5.25 \%)$ in summer and in ST 4 (5.43\%) in autumn. Minimum concentration was determined in ST 16 (1.88\%) in winter, in ST 3 (1.50) in spring, in ST 2 (2.25\%) in summer, and in ST $10(2.62 \%)$ in autumn. According to the spatial distribution analysis, high concentrations of TOC were detected at the mouth of the Poligon Stream in spring and summer. TOC concentration was especially high in the mouths of Manda Creek, Arap Creek and Melez Creek in summer. This finding shows that rivers are effective on seasonal and spatial distribution of TOC. Dense TOC concentration in river mouths and around ST 10 strengthens the possibility of its allochthonous character.

Chl-a concentration was minimum in ST 14 and maximum in ST 9 in all seasons. According to spatial analysis, maximum Chl-a concentration was detected in stations (ST 10 and ST 11) far from stream inputs in all seasons although Chl-a was relatively moderate in the mouth of Manda Creek, Arap Creek and Melez Creek in spring and summer. This situation shows that Chl-a is produced in the inner gulf, has been subjected to minimum rainfall conditions and seasonal changes and is discharged by rivers in minimal concentration.

Bsi was at maximum levels in ST 9 and at minimum levels in ST 14 in all seasons. The seasonal and spatial distribution similarity between Bsi and Chl-a is striking. This shows that diatoms significantly contribute to the phytoplankton biome. Increases in algae biome were found to be localized around ST 9 rather than the estuaries. Detailed temporal and spatial changes of TOC, $\mathrm{Chl}-\mathrm{a}, \mathrm{CaCO}_{3}$ and $\mathrm{Bsi}$ are presented in Figure 4.

$\mathrm{CaCO}_{3}$ concentration was at maximum in ST $3(11 \%)$ in winter, in ST $11(8.33 \%)$ in spring, in ST 1 (7.33\%) in summer, and in ST 16 in autumn (9.67\%). Minimum values were identified in ST 14 (2.67\%) in winter, in ST 7 (3.33\%) and ST 15 in spring, in ST 15 (3.67\%) in summer, and in ST 15 (3.33\%) in autumn. According to spatial analysis, $\mathrm{CaCO}_{3}$ reached high concentrations around ST 1, ST 2 and ST 3 at the mouth of Arap Creek, Melez Creek, Manda Creek and Bornova Stream in winter, summer and autumn (Figure 4). High $\mathrm{CaCO}_{3}$ concentration at this point is related to the sedimentation of the Miocene lacustrine $\mathrm{CaCO}_{3}$ in Arap Creek and Melez Creek basins (MTA, 2021). The source of the high $\mathrm{CaCO}_{3}$ concentration detected in the stations close to the mouth of the Poligon Stream in the spring is related to the upper Senonian clastic $\mathrm{CaCO}_{3}$ rocks in the stream basin (MTA, 2021). There are no geological formations that can be a source of $\mathrm{CaCO}_{3}$ on the southern shores of the İzmir Inner Gulf, except for the Poligon Stream, Arap Creek and Melez Creek basins. In this case, the $\mathrm{CaCO}_{3}$ concentration is expected to reach the maximum concentration only in the specified river mouths. However, the maximum concentrations identified in ST 11 (8.33\%) in spring and ST 16 in autumn (9.67\%) were not related to stream inputs. The maximum values in ST 16 in the west of the mouth of Poligon Stream and in ST 11 in the east were distributed in line with the flow directions. This situation indicates that the currents in the inner gulf may have an effect on the spatial distribution of metals and other variables, especially $\mathrm{CaCO}_{3}$. 

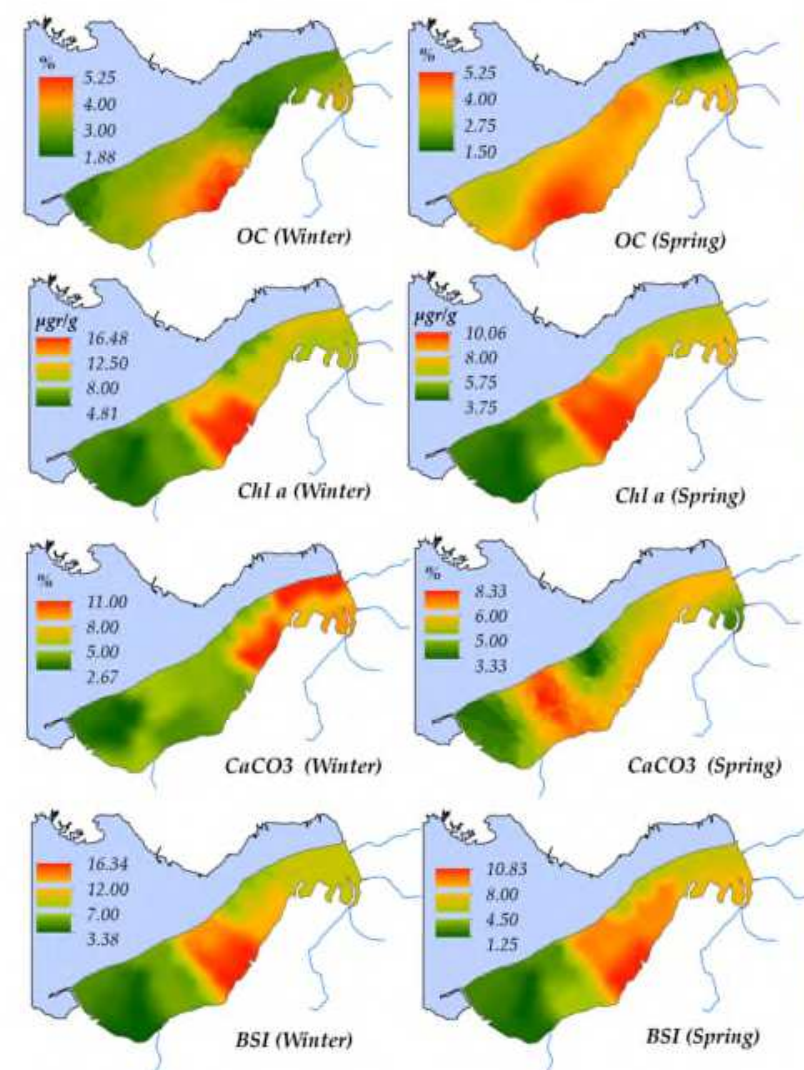
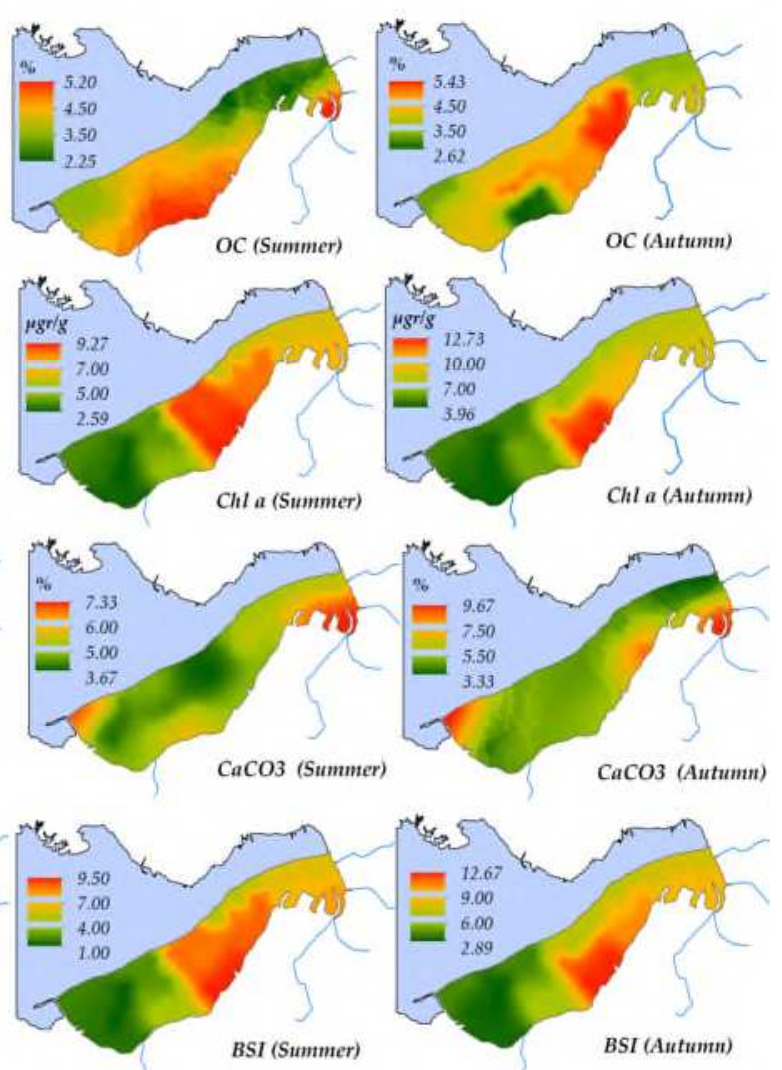

Figure 4: Spatial and seasonal change of TOC, Chl-a, $\mathrm{CaCO}_{3}$ and Bsi

\subsection{Evaluation of metal enrichments}

The metals were listed as follows according to EF general average data: $\mathrm{Mo}(9.80)>\mathrm{Pb}(5.59)>\mathrm{Cu}$ $(4.86)>\mathrm{Cd}(3.83)>\mathrm{Zn}(2.92)>\mathrm{Fe}(1.42)>\mathrm{Mn}(1.03)>\mathrm{Ni}(0.89)>\mathrm{Co}(0.81)>\mathrm{As}(0.71)>\mathrm{Cr}(0.39)$ $>\mathrm{Hg}(0.14)$. Accordingly, $\mathrm{Mo}$ and $\mathrm{Pb}$ were significantly enriched while $\mathrm{Cu}, \mathrm{Cd}, \mathrm{Zn}$ were moderately enriched. Other metals were classified as "minimal or no enrichment" (Figures 5 and 6).The maximum EF for As (1.22) was identified in ST 1 in autumn and the minimum EF (0.52) was identified in ST 15 in the summer and autumn. According to spatial analyses, it was determined that high EF values were concentrated around ST 1, ST 2 and ST 3 where river mouths are located in all seasons, but As did not exceed the threshold value in any of the stations.Cd enriched significantly by reaching the maximum EF in winter (7.43), in summer (6.26) and in autumn (9.04) in ST 10 and in the spring (6.22), in ST 11. According to the spatial distribution analyses, the possible source of the anthropogenic effect around ST 10 and ST 11 is the Poligon Stream, where domestic waste and sewage discharge has been carried out for many years. As it is well documented, domestic wastes and sewage leaks are included among the most important anthropogenic resources of Cd (Merhaby et al., 2018). Ports and transportation networks are other important anthropogenic resources of Cd (Jeong et al., 2020). Accordingly, the possible source of high EF values around ST 4 is the port and the source of the high accumulation detected along the southern shores of the gulf is the highway Because transportation networks can affect $\mathrm{Cd}, \mathrm{Pb}$ and $\mathrm{Zn}$ concentrations up to 320 meters away (Viard et al., 2004). Cr was not enriched in any of the seasons. Maximum EF (0.58) was determined in ST 9 in autumn and minimum EF (0.27) was identified in ST 14 in autumn. Cu significantly enriched by reaching the maximum level in ST 4 in winter (8.88) and in summer (7.65) and in ST 1 in spring (6.80) and in autumn (9.57). There is no river input around ST 4, but there is a port that has been used for many years. Therefore, the likely source of $\mathrm{Cu}$ enrichment around ST 4 is the port. The Manda Creek, Arap Creek and Melez Creek, 
which discharge into the inner gulf near ST 1, pass through the regions where industry and urbanization activities are the most intense. In this case, the reason for the enrichment around ST 1 may be the discharge of domestic and industrial wastes to the inner gulf by the rivers. The fact that $\mathrm{Cu}$ is affected by anthropogenic activities taking place in port regions has been identified in some busy ports in various countries of the world (Chen et al., 2020; Jeong et al., 2020; Jahan and Strezov, 2018). Fe did not show significant accumulation in other seasons, except for the significant level of enrichment (5.47) in ST 4 in the spring. The only source for such unnatural accumulation around ST 4 is the port. Possible source of enrichment here may be the discharge from ships. Hg has not been enriched in any season. However, maximum EF levels were detected in winter (0.46), in summer (0.21) and in autumn (0.23) in ST 4 and in spring (0.31) in ST 1. According to the spatial distribution of $\mathrm{Hg}$, domestic and industrial wastes arrive though Manda Creek, Arap Creek and Melez Creek in the spring and a small amount of anthropogenic effect is experienced as a result of the port in other seasons. Hg not pose an ecological risk hazard due to enrichment. The maximum values detected in three seasons in ST 4, where the port is located, may be related to the anthropogenic activities taking place in the port area because $\mathrm{Hg}$ is an important pollutant in port areas (Chen et al, 2020; Jahan and Strezov, 2018). Mn reached the maximum enrichment in winter (2.84), in spring (8.35) and in autumn (1.20) in ST 4 and in summer (1.01) in ST 1. According to these data, there was a moderate enrichment for Mn in ST 4 in winter and and significant enrichment in the spring. Mn did not exceed the threshold value of 2 in any stations during summer and autumn. Spatial analyses showed that $\mathrm{Mn}$ was enriched in winter and spring with anthropogenic effects originating from the port. Discharges from ships, maintenance and shipping activities in ports can be a source of Mn (Oliveira et al., 2020). Mo reached maximum enrichment in ST 10 in winter (19.94), in ST 13 in spring (19.98), in ST 9 in summer (19.29) and in ST 9 in autumn (27.16). Mo was very highly enriched in autumn and significantly enriched in other seasons. According to spatial analyses, in winter, Poligon Stream discharges Mo which has a significant anthropogenic effect. Mo is an important pollutant for sediment and undersea fauna in coastal areas (Rumisha et al., 2012). Ni did not demonstrate any anthropogenic accumulation in any season. However, the maximum enrichment in the mouths of the Manda Creek, Arap Creek, Bornova Stream and Melez Creek in the spring and the mouth of the Bornova Stream in the summer shows that the streams discharge $\mathrm{Ni}$ with minimal anthropogenic effect. $\mathrm{Pb}$ enriched significantly by reaching maximum values in winter (10.54) in ST 4, in spring (13.15) in ST 1, in summer (10.21) in ST 2 and in autumn (12.42) in ST 1 and ST 2. Possible source of the enrichment in winter is the port and the source of the enrichment in the stations at the mouths of the Manda Creek, Melez Creek, Arap Creek and Bornova Stream in other seasons is industrial- domestic wastes and the port. $\mathrm{Pb}$ is an important anthropogenic pollutant in port areas (Che et al, 2020; Jeong et al., 2020). $\mathrm{Zn}$ showed maximum enrichment in winter (4.41) in ST 9, in spring (4.25) in ST 11, in summer (4.51) in ST 4 and ST 10 and in autumn (5.03) in ST 9. According to this finding, Zn enriched in the lower limits of the significant level in autumn and enriched moderately in other seasons. Spatial analyses show that $\mathrm{Zn}$ was enriched in spring and summer near the mouth of the Poligon Stream. $\mathrm{Zn}$ is a major pollutant that can result from domestic waste and sewage (Merhaby et al., 2018). Poligon Stream has been an area where domestic wastes and sewers have been discharged for many years. Possible reason for the enrichment in ST 4 is the port because, $\mathrm{Zn}$ is a metal that is frequently encountered in port areas and can easily be absorbed into the underwater fauna (Beneditto et al., 2019). 


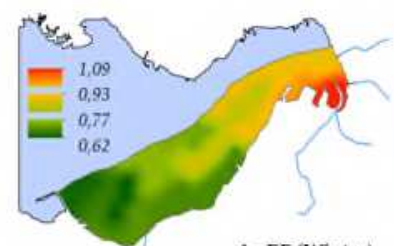

As EF (Winter)

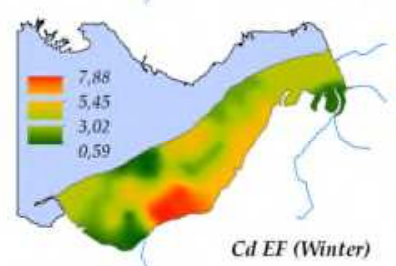

Cd EF (Winter)

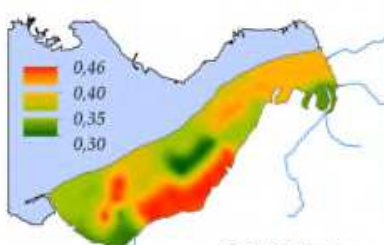

CrEF (Winter)
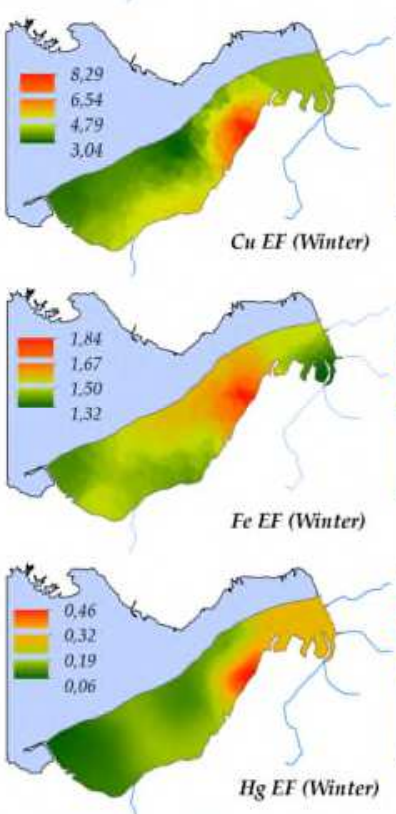
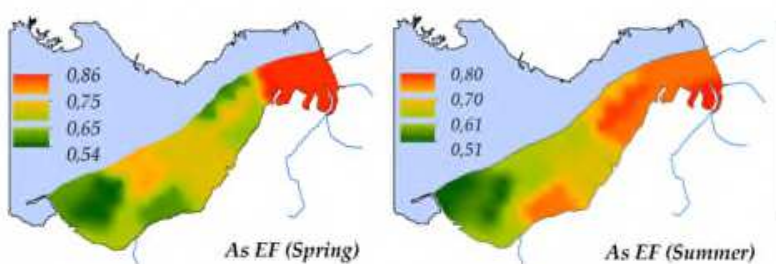

As EF (Summer)

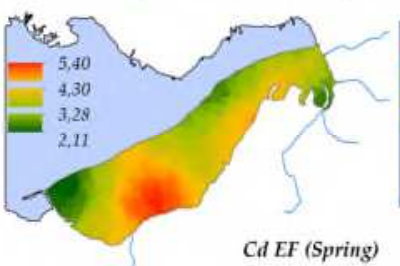

Cd EF (Spring)
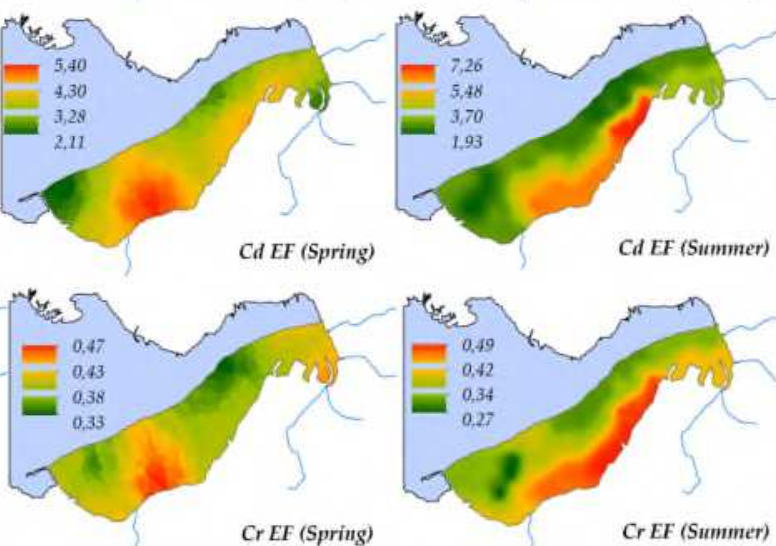

Cd EF (Summer)

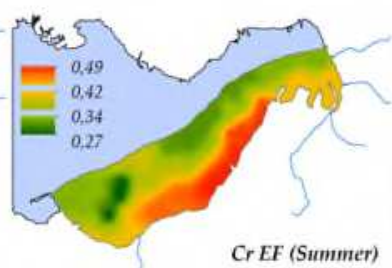

Cr EF (Summer)
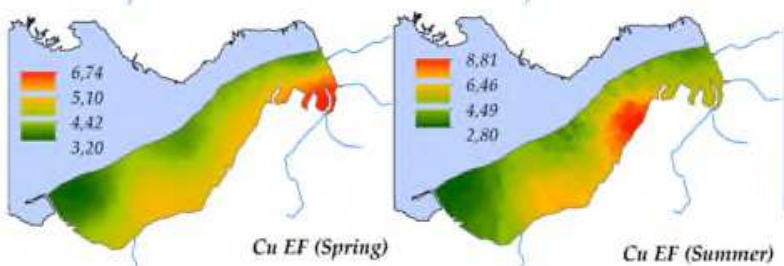

Cu EF (Summer)
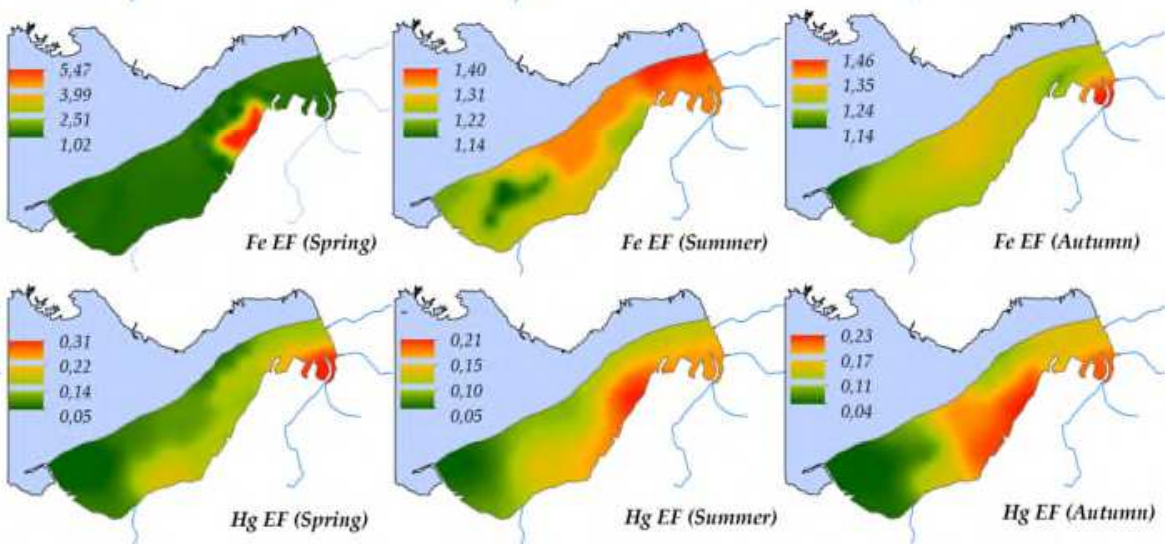

Figure 5: Spatial and seasonal change of EF (part 01) 

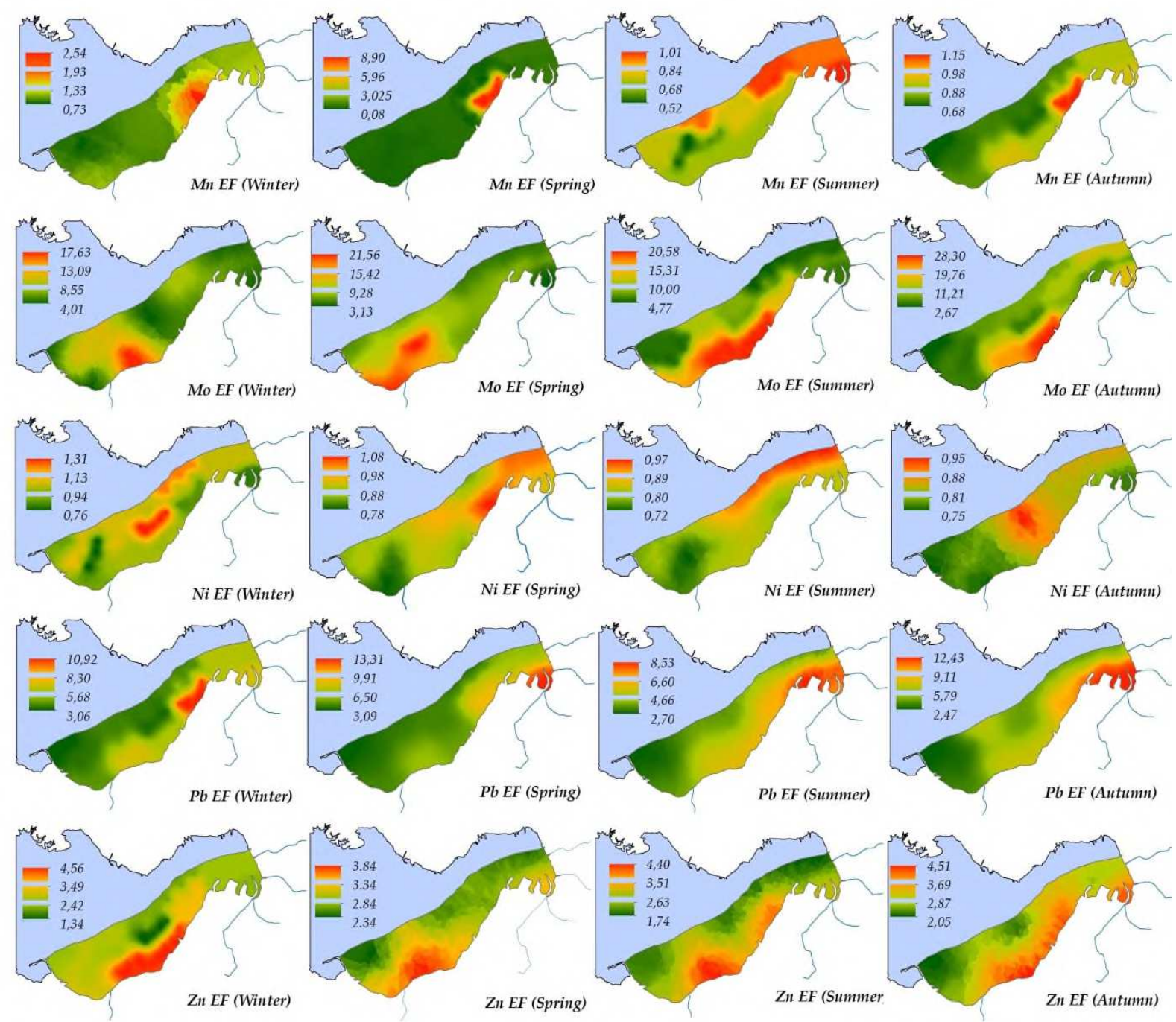

Figure 6: Spatial and seasonal change of EF (part 02)

Based on the average of all seasons, $\mathrm{I}_{\text {geo }}$ was listed as: $\mathrm{Mo}(3.68)>\mathrm{Pb}(2.97)>\mathrm{Cu}(2.82)>\mathrm{Cd}(2.39)>$

$424 \mathrm{Zn}(2.11)>\mathrm{Fe}(1.08)>\mathrm{Mn}(0.47)>\mathrm{Ni}(0.43)>\mathrm{Co}(0.30)>\mathrm{As}(0.09)>\mathrm{Cr}(-0.77)>\mathrm{Hg}(-2.40)$

425 (Figure 7). According to these data, İzmir Inner Gulf was moderately contaminated with Mo; slightly 426 contaminated with $\mathrm{Pb}, \mathrm{Cu}, \mathrm{Cd}, \mathrm{Zn}, \mathrm{Fe}, \mathrm{Mn}, \mathrm{Ni}, \mathrm{Co}$, As while it was not contaminated with $\mathrm{Cr}$ and $\mathrm{Hg}$. 427 However, the minimum and maximum values observed in some stations resulted in the seasonal and 428 spatial change of the pollution degrees. Possible sources of metals with an anthropogenic effect are defined in the EF section. 

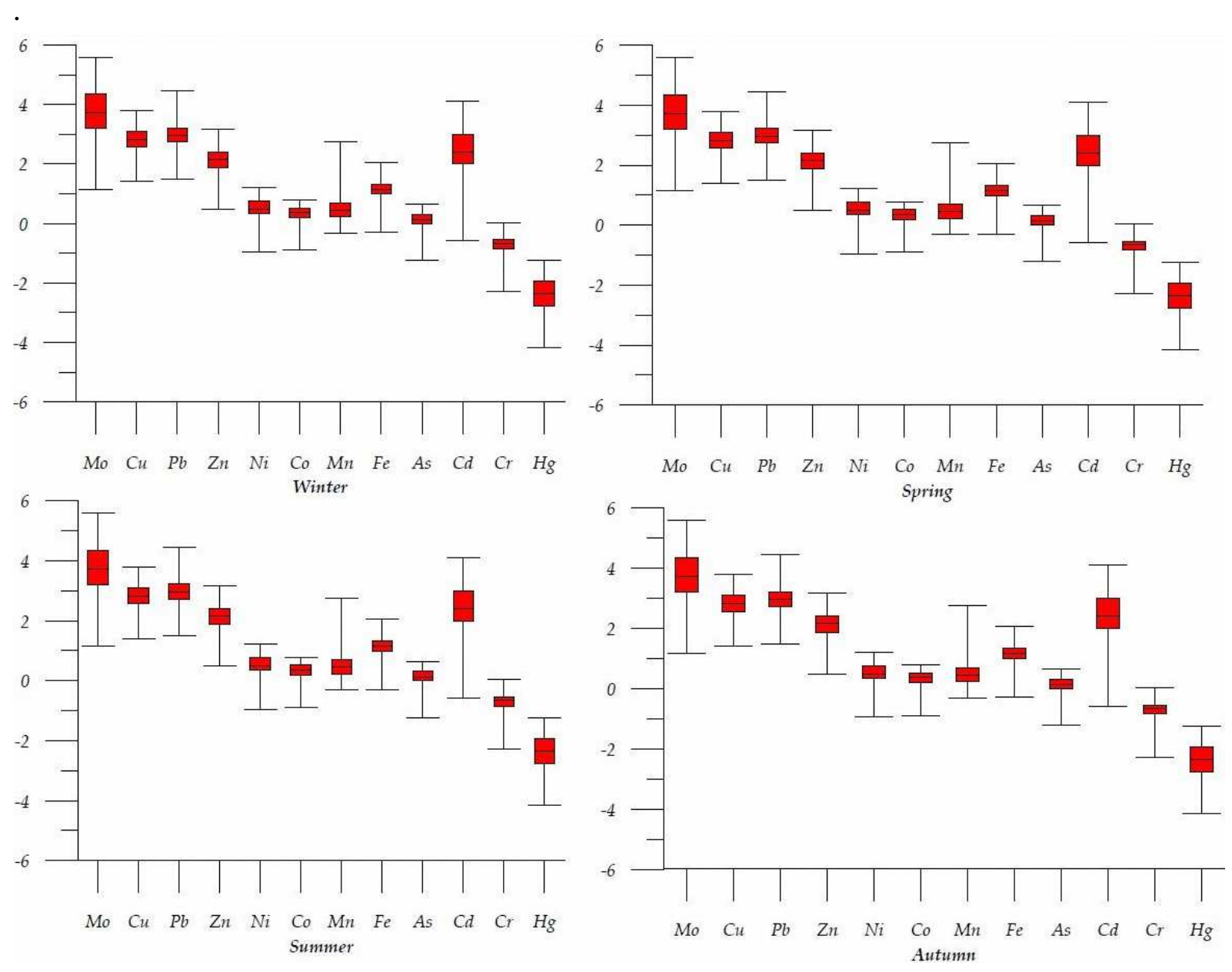

Figure 7: Box and whisker plot of $I_{g e o}$ values

\subsection{Ecological and ecotoxicological risk assessment of metals}

According to the average data, the mHQ index ranked as Ni (2.87) $>\mathrm{Cr}(2.65)>\mathrm{As}(2.42)>\mathrm{Hg}(2.03)$ $>\mathrm{Pb}(1.83)>\mathrm{Zn}(1.63)>\mathrm{Cu}(1.63)>\mathrm{Cd}(0.93)$. Accordingly, high level of risk was identified for $\mathrm{Ni}$ and $\mathrm{Cr}$, significant level of risk was identified for As and $\mathrm{Hg}$, medium level of risk was identified for $\mathrm{Pb}, \mathrm{Zn}, \mathrm{Cu}$ and very low level of risk was identified for $\mathrm{Cd}$. Maximum mHQ was detected for $\mathrm{Ni}$ (3.71) in winter in ST 10, for $\mathrm{Cr}$ (3.21) in spring in ST 11, for As (2.92) in winter in ST 6, for $\mathrm{Hg}$ (2.85) in winter in ST 2, for $\mathrm{Pb}$ (2.47) in summer in ST 4, for Zn (2.32) in autumn in ST 9, for $\mathrm{Cu}$ (2.24) in summer in ST 4, for Cd (1.28) in summer and in winter in ST 10. Minimum mHQ was detected for Ni (1.76) in winter in ST 1, for $\mathrm{Cr}$ (1.56) in winter in ST 1, for As (1.53) in autumn in ST 16, for $\mathrm{Hg}(1.08)$ in autumn in ST 16, for Pb (1.08) in autumn in ST 16, (0.92) for Zn in winter in ST 1 , for $\mathrm{Cu}(0.99)$ in winter in ST 1 and for Cd (0.32) in winter in ST 1. Spatial analyses show that the minimum mHQ was concentrated in the ST 1 located at the mouth of the Manda Creek, Melez Creek, Arap Creek and in winter (Figure 8). It is believed that this situation is caused by the high flow rates into the inner gulf from the streams in the winter months, when the maximum precipitation falls, 

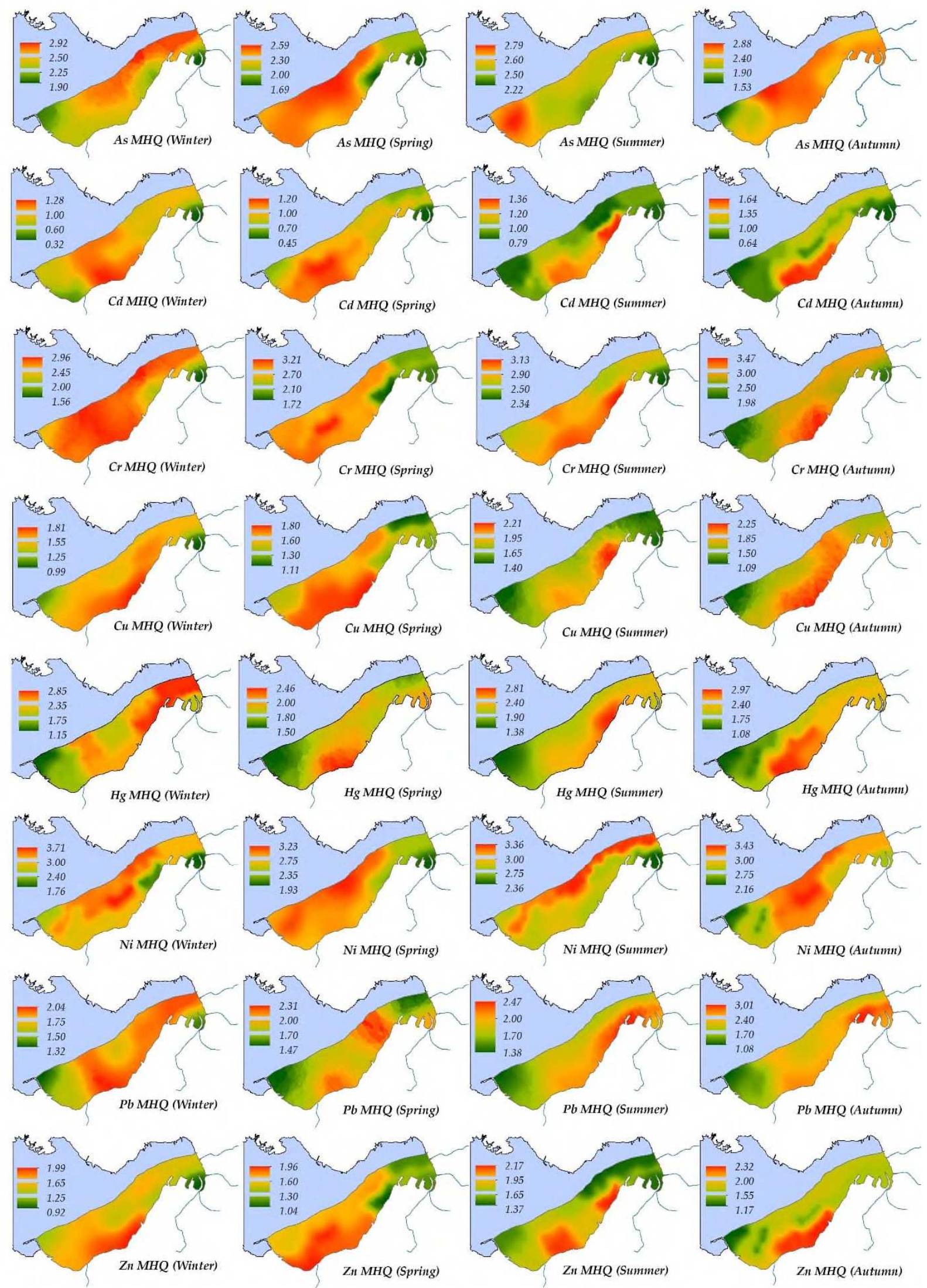

Figure 8: Spatial and seasonal change of MHQ 
ECI values ranged from 3.80 to 6.26 in winter and averaged 5.56. ECI reached a maximum (6.26) around ST 3 in winter. This situation indicates that the ST 11 environment was highly polluted. Minimum ECI (3.80) was observed in ST 1. Accordingly, ST 1 pointed to a mild to moderate contamination level in winter. The ECI was between 4.30 and 6.11 in the spring and averaged 5.46. In ECI reached to the maximum (6.15) level in ST 11 and created a high degree of pollution. In the spring, the minimum ECI (4.30) was observed around ST 4. At this point, moderate pollution was detected. ECI was 5.86 in summer on average, ranging from 5.00 to 6.49. The maximum value (6.49) was observed in ST 10 near the mouth of the Poligon Stream in the summer and a high degree of pollution was detected. The minimum value (5) was observed in ST 16, which was moderately dirty. In autumn, the maximum ECI (7.11) was observed in ST 9 and the minimum ECI (3.84) in ST 16. ECI was 5.82 on average. Accordingly, there was high pollution around ST 9 and slight-moderate pollution around ST 16. The average ECI of four seasons was 5.67. Accordingly, the whole inner gulf was highly polluted in winter. According to the spatial analyses data, the maximum ECI was concentrated in ST 9 ST 10 and ST 11, the stations close to the mouth of the Poligon Stream (Figure 10). This situation shows that the Poligon Stream plays an important role in the pollution of the inner gulf. created significant ecological risks in all seasons throughout the inner gulf, other metals did not create ecological risks in any season. However, the MRI values detected in some seasons were observed to create an ecological risk. According to spatial analyses, As did not pose an ecological risk, but reached its maximum ecological risk level around ST 1 in winter (10.95), spring (8.49), summer (8.02) and autumn (12.06). This finding shows that in case of an increase in anthropogenic resources, the streams and ports passing through the city and industrial zone may create a risk of As pollution in the inner inner gulf. As values were at minimum in winter (6.17), spring (5.57) and autumn (5.27) in Station 14 and in summer (5.20) in Station 15. Cd was at the maximum ecological risk level in ST 10 in winter (222), summer (187) and autumn (271) and in ST 11 in spring (186). A high degree of ecological risk has been identified in the vicinity of the aforementioned stations. This situation is attributed to the anthropogenic Cd sources in the Poligon Stream basin. Minimum ecological risk values for Cd were determined in winter (27) in ST 13, in spring (51) in ST 16, in summer (59) in ST 15 and in autumn (57) in ST 15. 

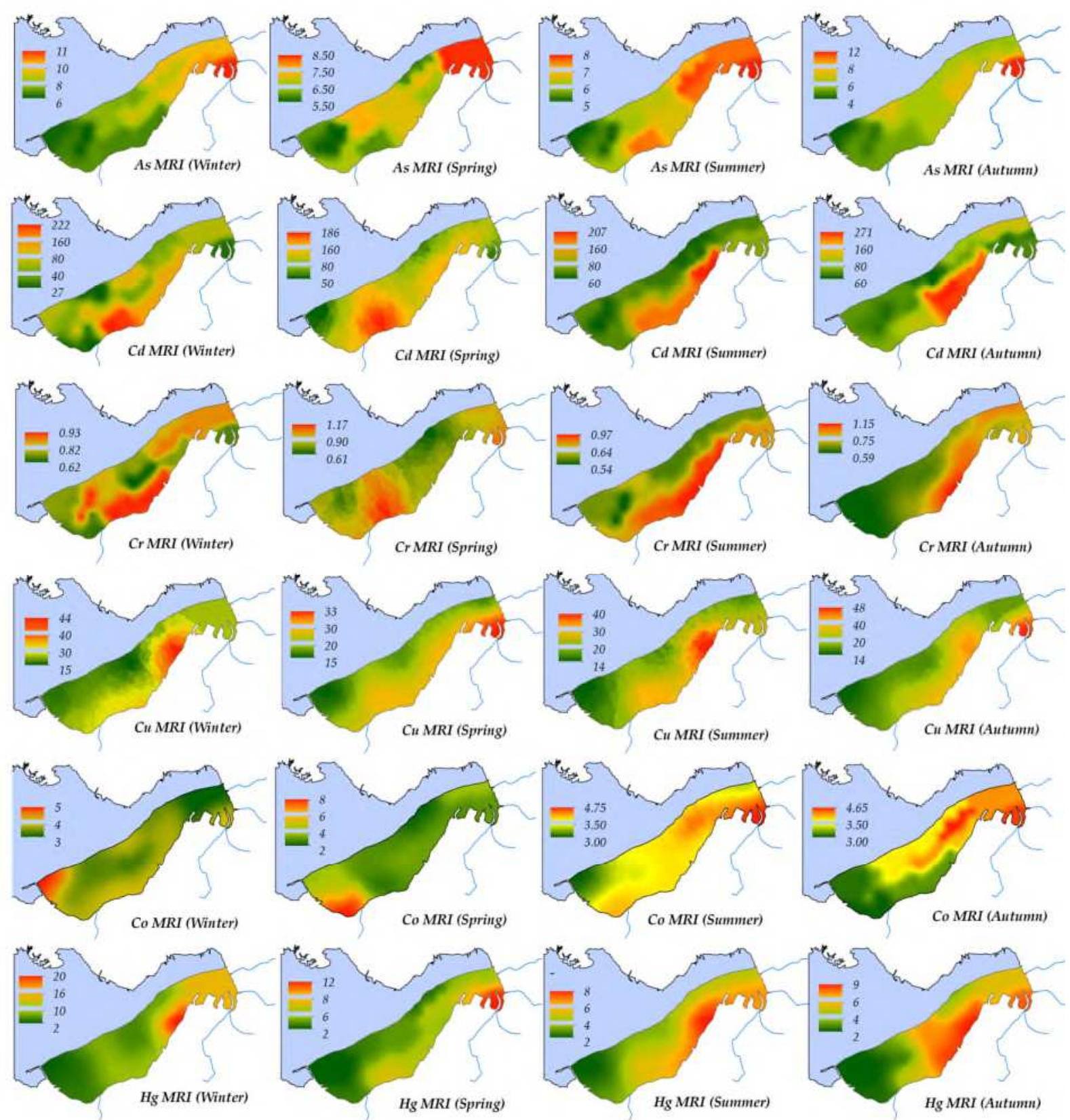

Figure 9: Spatial and seasonal change of MRI (part 01)

$\mathrm{Cr}$ did not create an ecological risk in any station and season. Maximum ecological risk values for $\mathrm{Cu}$ were identified in winter (44) in ST 4, in spring (34) in ST 1, in autumn (41) in ST 5 and in summer (48) in ST 1. Accordingly, Cu was found to create a moderate ecological risk in winter and autumn in ST 4 and ST 5 near the port and in summer in ST 1 where Arap Creek, Melez Creek and Manda Creek discharge. Minimum ecological risk values for $\mathrm{Cu}$ were identified in winter (15.50) in ST 16, in spring (15.88) in ST 15, in summer (14.19) in ST 6 and in autumn (14.26) in ST 16. Co, Hg, Mn, Ni and Zn did not create an ecological risk in any station or season. Figures 9 and 10 present the spatial distribution analyses of these metals. $\mathrm{Pb}$ reached the maximum ecological risk value in winter (52) in ST 4, in spring (65) in ST 1, in summer (51) and autumn (62) in ST 2 and created a moderate ecological risk in the aforesaid station areas. According to spatial analyses, $\mathrm{Pb}$ created an ecological risk due to the the harbor in winter and due to anthropogenic effects discharged by the Manda Creek, 

in all seasons.
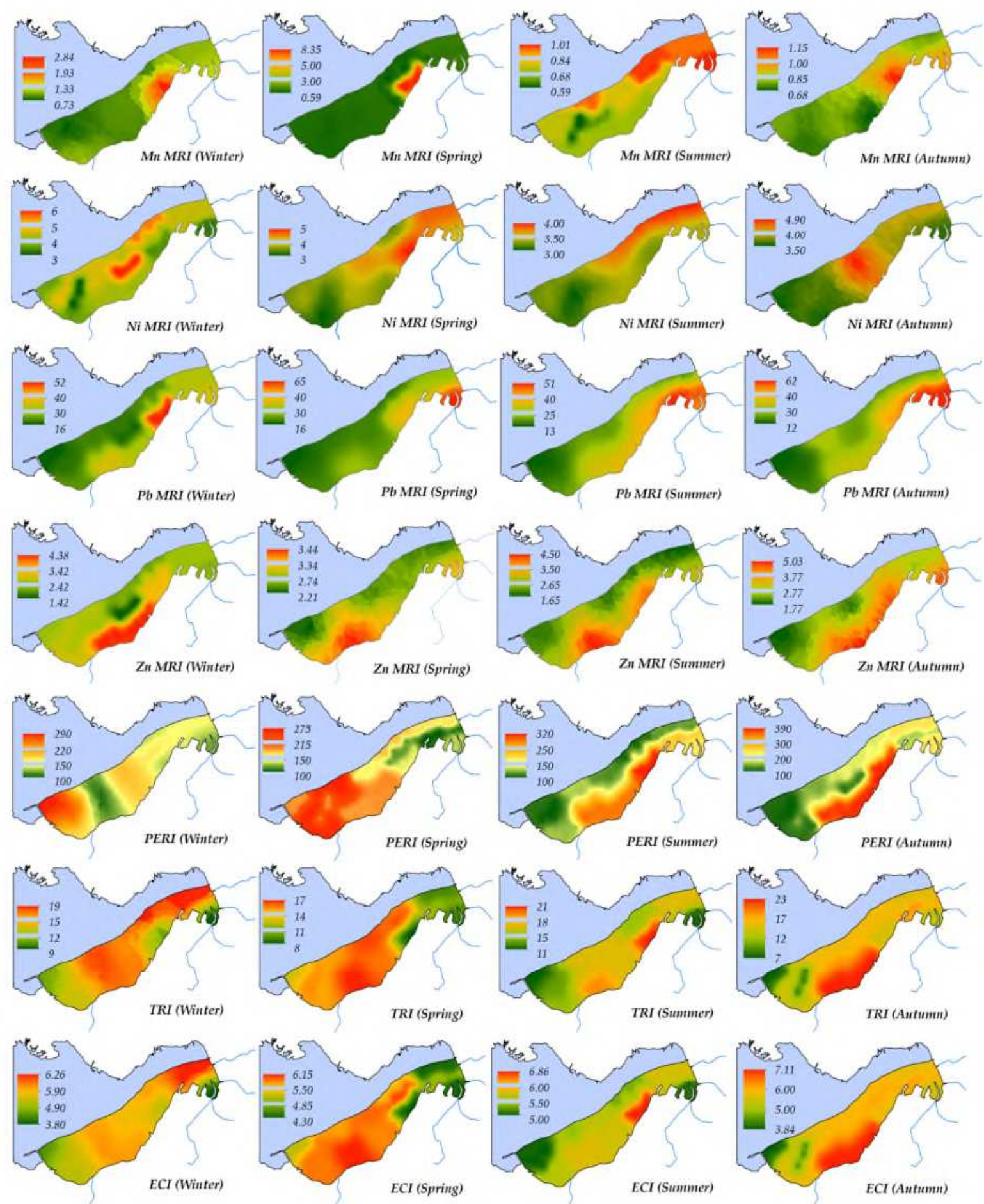

Figure 10: Spatial and seasonal change of MRI, PERI, TRI and ECI (part 02)

PERI average for four seasons was 193. Accordingly, a moderate potential ecological risk was found to exist in the inner gulf. When examined seasonally; winter average of PERI was 187 . There was a moderate ecological risk in the inner gulf during the winter season. PERI increased to the maximum in winter (314) in ST 10, creating a significant potential ecological risk. The reason for this situation was the Cd discharged by Poligon Stream. PERI was at minimum levels (95) around ST 13. Low potential 
ecological risk was detected in ST 1, ST 6, ST 8 and ST 12 in winter and moderate potential ecological risk was detected in other stations (Figure 10).

PERI average for spring was 190, and the maximum (270) and minimum value (100) were observed in ST 11 and ST 16 respectively. A moderate ecological risk existed in the whole inner gulf in the spring except for ST 15 and ST 16. Cd was the reason for the ecological risk. In the spring, high (265) MRI values around ST 4 (263) and ST 2, where the port is located, drew attention. This indicates that ports have an impact on the potential increase in ecological risk.

PERI average for summer was 184 . There was a moderate potential ecological risk in the inner gulf in summer. PERI created a significant potential ecological risk by reaching the maximum (308) in ST 4, while the minimum value (110) was observed in ST 15. Low ecological risk was identified in ST 3, ST 4, ST 5, ST 6, ST 14, ST 15 and ST 16 in summer.

PERI average for autumn was 210 and a moderate ecological risk was identified in the inner gulf. PERI was found to be at the maximum (373) level in ST 4 and at the minimum (106) level in ST 15. Accordingly, there was a significant ecological risk around ST 4, low ecological risk around ST 8, ST 13, ST 15, ST 16 and moderate potential ecological risk in other areas.

Generally speaking, a moderate ecological risk has been identified in all seasons throughout the İzmir Inner Gulf. Ecological risk is low in certain stations in some seasons while it is significant in some stations in some seasons. Figure 10 presents the detailed spatial distribution of PERI.

According to average values, TRI was (16.65) in winter, (15.65) in spring, (17.93) in summer and (17.85) in autumn. Accordingly, a significant toxic risk existed in all seasons. The order of responsibility of metals from TRI is $\mathrm{Ni}>\mathrm{Cr}>\mathrm{As}>\mathrm{Hg}>\mathrm{Pb}>\mathrm{Zn}>\mathrm{Cu}>\mathrm{Cd}$. According to the spatial distribution of TRI, the maximum value was determined in ST 9 (25.17) in autumn and the minimum value in ST 16 in autumn. Maximum TRI values were observed in ST 11 near the mouth of the Poligon Stream in winter and spring, in ST 4 near the harbor in summer, and in ST 9 in the autumn (Figure 10). Accordingly, anthropogenic activities in the harbor and Poligon Stream cause an increase in the toxic risk in the inner gulf.

\subsection{Multivariate statistical analysis}

Four factors with an eigenvalue> 1 were identified for factor analysis. These factors explained $79.59 \%$ of the total variance. The first factor explained $38.44 \%$ of the variance and consisted of TOC, $\mathrm{Mo}, \mathrm{Cu}$, $\mathrm{Pb}, \mathrm{Zn}, \mathrm{Cd}$ and $\mathrm{Cr}$. This factor represented the anthropogenic effect. $\mathrm{Mo}, \mathrm{Cu}, \mathrm{Pb}, \mathrm{Zn}$ and $\mathrm{Cd}$ are elements of anthropogenic origin, which are in the moderate-significant class according to EF and $\mathrm{I}_{\text {geo. }}$. TOC, on the other hand, is related to eutrophication, which is one of the most important problems of the İzmir Inner Gulf. $\mathrm{Cr}$ is the only element in this factor with a low enrichment value. It is also included in the second factor with a weight close to its load in the first factor. This indicates that $\mathrm{Cr}$ has mixed resources. The second factor explained $19.04 \%$ of the total variance and consisted of $\mathrm{Ni}$, $\mathrm{Co}, \mathrm{As}, \mathrm{Cr}$, $\mathrm{Ti}$ (positive load) and $\mathrm{CaCO}_{3}$ (negative load). This factor represented lithogenic sources. All elements included in the factor were lithophile elements with low enrichment and Igeo values. The third factor explained $15.24 \%$ of the total variance and consisted of Chl-a, Bsi, and $\mathrm{Hg}$. This factor represented primary production. It consisted of Chl-a and biogenic silica accumulated in the sediment, as well as $\mathrm{Hg}$. The participation of $\mathrm{Hg}$ in this factor may be related to the transport of algae from water to sediment, depending on the uptake. The fourth and the final factor explained $6.87 \%$ of the total variance and consisted of $\mathrm{Fe}$ and $\mathrm{Mn}$. This factor also represented rock erosion similar to factor 2 . 
However, the presence of these two elements in a different factor may be due to differences in transport processes (Table 2).

Table 2: Factor analysis

\begin{tabular}{lllll}
\hline & Factor 1 & Factor 2 & Factor 3 & Factor 4 \\
\hline $\mathrm{TOC}$ & $\mathbf{0 . 5 0}$ & -0.01 & 0.10 & -0.14 \\
$\mathrm{CaCO}_{3}$ & -0.03 & $\mathbf{- 0 . 6 0}$ & 0.29 & 0.10 \\
$\mathrm{Mo}$ & $\mathbf{0 . 8 6}$ & 0.23 & -0.17 & -0.01 \\
$\mathrm{Cu}$ & $\mathbf{0 . 8 8}$ & 0.14 & 0.15 & 0.00 \\
$\mathrm{~Pb}$ & $\mathbf{0 . 5 8}$ & 0.04 & 0.42 & 0.10 \\
$\mathrm{Zn}$ & $\mathbf{0 . 9 1}$ & 0.26 & -0.06 & -0.08 \\
$\mathrm{Ni}$ & 0.03 & $\mathbf{0 . 9 6}$ & 0.08 & 0.08 \\
$\mathrm{Co}$ & 0.22 & $\mathbf{0 . 8 6}$ & 0.11 & 0.33 \\
$\mathrm{Mn}$ & -0.17 & 0.00 & 0.14 & $\mathbf{0 . 9 6}$ \\
$\mathrm{Fe}$ & 0.06 & 0.67 & -0.05 & $\mathbf{0 . 7 2}$ \\
$\mathrm{As}$ & 0.24 & $\mathbf{0 . 8 3}$ & 0.26 & -0.02 \\
$\mathrm{Cd}$ & $\mathbf{0 . 8 5}$ & 0.14 & 0.04 & 0.04 \\
$\mathrm{Cr}$ & $\mathbf{0 . 7 0}$ & $\mathbf{0 . 6 4}$ & -0.05 & -0.09 \\
$\mathrm{Ti}$ & 0.27 & $\mathbf{0 . 8 8}$ & -0.22 & 0.04 \\
$\mathrm{Hg}$ & 0.56 & 0.02 & $\mathbf{0 . 6 4}$ & 0.02 \\
$\mathrm{Chl}-\mathrm{a}$ & -0.01 & 0.00 & $\mathbf{0 . 9 4}$ & 0.04 \\
$\mathrm{Bsi}$ & 0.01 & -0.06 & $\mathbf{0 . 9 6}$ & 0.06 \\
\hline
\end{tabular}

553 Based on the correlation test, TOC had a positive but weak relationship with $\mathrm{Mo}, \mathrm{Cu}, \mathrm{Pb}, \mathrm{Zn}, \mathrm{Cd}$ and $\mathrm{Cr}$. The role of TOC in transporting this element appeared to be low. $\mathrm{CaCO}_{3}$ had a weak negative relationship with $\mathrm{Mo}, \mathrm{Ni}, \mathrm{Co}, \mathrm{Fe}, \mathrm{Cr}$ and Ti. Accordingly, $\mathrm{CaCO}_{3}$ is believed to have no function in the distribution of metals. $\mathrm{Cu}, \mathrm{Pb}, \mathrm{Zn}, \mathrm{Cd}$ and $\mathrm{Mo}$ with anthropogenic enrichment had strong positive correlations with each other. These elements are thought to share source and transport processes. Apart from these elements, Mo had a relationship with $\mathrm{Ni}, \mathrm{Co}, \mathrm{Fe}, \mathrm{As}, \mathrm{Cr}$, $\mathrm{Ti}$ and $\mathrm{Hg}$, but its relationship was weak with other elements except $\mathrm{Cr}$. Ni, $\mathrm{Co}, \mathrm{Mn}, \mathrm{Fe}, \mathrm{As}$, and Ti displayed a strong relationship with each other and a relatively weak relationship with $\mathrm{Cr}$. The low enrichment values of these elements and the relationships between them showed that they were transported from natural resources to the inner gulf by common transportation processes. Although $\mathrm{Hg}$ is an element that does not show enrichment, it had a weak correlation with $\mathrm{Mo}, \mathrm{Cd}$ and $\mathrm{Cu}$ of anthropogenic origin, had a strong correlation with $\mathrm{Pb}$ and weak correlation with $\mathrm{As}$ and $\mathrm{Ti}$, which are naturally sourced elements. This situation may refer to the similarity in the transportation processes rather than the common source. $\mathrm{Chl}-\mathrm{a}$, which represents primary productivity, had a positive weak relationship with $\mathrm{Mn}$ and $\mathrm{Pb}$ and a negative weak relationship with Ti. Similarly, Bsi showed a weak positive relationship with $\mathrm{Pb}$ and a negative weak relationship with Ti. This situation indicates that phytoplankton play a partial role in the transport of lead to the sediment. The 0.99 correlation between Bsi and Chl-a indicated that the contribution of diodes to the concentration of Chl-a was important, and that the diotames controlled the Chl-a concentration. The absence of a statistically significant correlation between these two parameters representing primary production and TOC suggests that the carbon source may be allochthonous (Table 3). 


\begin{tabular}{|c|c|c|c|c|c|c|c|c|c|c|c|c|c|c|c|c|c|}
\hline & TOC & $\mathrm{CaCO}_{3}$ & Mo & $\mathrm{Cu}$ & $\mathrm{Pb}$ & $\mathrm{Zn}$ & $\mathrm{Ni}$ & Co & $\mathrm{Mn}$ & $\mathrm{Fe}$ & As & $\mathrm{Cd}$ & $\mathrm{Cr}$ & $\mathrm{Ti}$ & $\mathrm{Hg}$ & Chl- $a$ & Bsi \\
\hline TOC & & & & & & & & & & & & & & & & & \\
\hline $\mathrm{CaCO}_{3}$ & -0.05 & & & & & & & & & & & & & & & & \\
\hline Mo & 0.35 & -0.28 & & & & & & & & & & & & & & & \\
\hline $\mathrm{Cu}$ & 0.49 & -0.01 & 0.65 & & & & & & & & & & & & & & \\
\hline $\mathrm{Pb}$ & 0.39 & 0.17 & 0.48 & 0.65 & & & & & & & & & & & & & \\
\hline $\mathrm{Zn}$ & 0.50 & -0.21 & 0.80 & 0.83 & 0.51 & & & & & & & & & & & & \\
\hline $\mathrm{Ni}$ & -0.05 & -0.43 & 0.32 & 0.04 & 0.02 & 0.23 & & & & & & & & & & & \\
\hline Co & 0.00 & -0.35 & 0.36 & 0.23 & 0.24 & 0.20 & 0.76 & & & & & & & & & & \\
\hline $\mathrm{Mn}$ & -0.21 & -0.04 & -0.08 & -0.03 & 0.16 & -0.07 & 0.62 & 0.68 & & & & & & & & & \\
\hline $\mathrm{Fe}$ & -0.13 & -0.39 & 0.25 & 0.00 & -0.04 & 0.14 & 0.85 & 0.79 & 0.72 & & & & & & & & \\
\hline As & -0.01 & -0.13 & 0.39 & 0.26 & 0.34 & 0.28 & 0.75 & 0.76 & 0.60 & 0.67 & & & & & & & \\
\hline $\mathrm{Cd}$ & 0.36 & -0.16 & 0.70 & 0.65 & 0.50 & 0.75 & 0.21 & 0.24 & -0.08 & 0.17 & 0.27 & & & & & & \\
\hline $\mathrm{Cr}$ & 0.33 & -0.36 & 0.85 & 0.57 & 0.42 & 0.79 & 0.49 & 0.47 & 0.08 & 0.34 & 0.46 & 0.65 & & & & & \\
\hline $\mathrm{Ti}$ & 0.03 & -0.48 & 0.43 & 0.25 & 0.00 & 0.37 & 0.76 & 0.74 & 0.45 & 0.78 & 0.64 & 0.29 & 0.49 & & & & \\
\hline $\mathrm{Hg}$ & 0.23 & 0.19 & 0.33 & 0.55 & 0.80 & 0.38 & 0.09 & 0.22 & 0.18 & -0.04 & 0.32 & 0.45 & 0.35 & -0.06 & & & \\
\hline Chl- $a$ & 0.12 & 0.18 & -0.17 & 0.11 & 0.43 & -0.09 & 0.01 & 0.12 & 0.25 & -0.04 & 0.19 & 0.05 & -0.06 & -0.29 & 0.60 & & \\
\hline Bsi & 0.14 & 0.20 & -0.19 & 0.11 & 0.45 & -0.10 & -0.01 & 0.10 & 0.25 & -0.06 & 0.17 & 0.04 & -0.08 & -0.31 & 0.60 & 0.99 & \\
\hline
\end{tabular}

Two important clusters are noteworthy according to the dendogram obtained from cluster analysis. One of them is the cluster representing the anthropogenic contribution among $\mathrm{Mo}, \mathrm{Cu}, \mathrm{Zn}, \mathrm{Cr}, \mathrm{Cd}$, and the other is the cluster representing the natural processes between Ni, Co, Ti, As, Fe, Mn. These two clusters are also compatible with the factor analysis results. The high affinity between Chl-a and Bsi was also consistent with the results of factor analysis and correlation test. Although there was a relationship between. $\mathrm{Hg}$ and $\mathrm{Pb}$, the distance of these two elements was grand. A similar result was encountered in the correlation test and a high correlation was found between the two elements (Figure 11). This similarity is thought to be based on common transport processes. TOC and $\mathrm{CaCO}_{3} \mathrm{did}$ not seem to play an important role in the transport and distribution of metals.

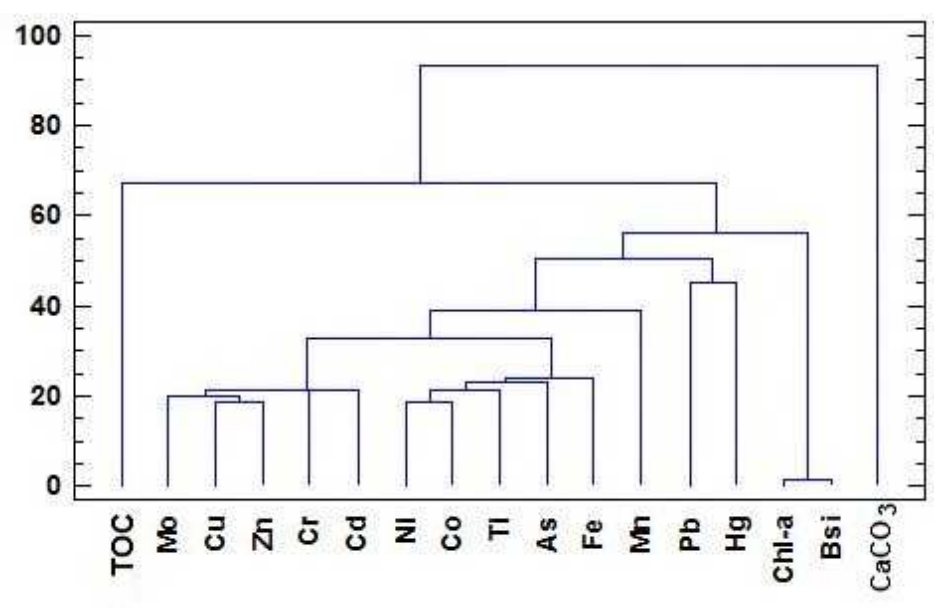

Figure 11: Cluster analysis 
One-way ANOVA was performed at $95 \%$ confidence interval to identify whether there was a difference between seasonal concentrations for each of the 17 variables measured in the study. While there was a significant difference between the seasons in the concentrations of $\mathrm{CaCO}_{3}, \mathrm{Cu}, \mathrm{Ti}, \mathrm{Chl}-\mathrm{a}$ and Bsi, no significant difference was found for the other elements. Multiple range test (LSD) was performed to detect the seasons which created difference. Accordingly, the $\mathrm{CaCO}_{3}$ concentration varied in the spring, but it had similar levels in the other three seasons. $\mathrm{Cu}$ concentration showed a significant difference between winter-summer, winter-autumn and spring-summer. From this point of view, it can be argued that there is a difference between dry seasons and humid seasons in terms of precipitation. For $\mathrm{Ti}$, a difference was observed between summer-spring and summer-winter. Considering that it is a lithophile element and is carried to the inner gulf by erosion, this difference between rainy and dry seasons is significant. Chl-a and Bsi concentrations showed statistically significant differences between winter-spring and winter-summer. This may be due to the fact that abiotic factors such as light and temperature that affect primary production stimulate the increase in plant biome with the arrival of summer.

\section{Conclusion}

According to results of the study, port management, industry, settlements and transportation activities carried out in the inner gulf of İzmir caused $\mathrm{Mo}, \mathrm{Pb}, \mathrm{Cu}, \mathrm{Cd}$ and $\mathrm{Zn}$ to be enriched with anthropogenic effects and diverge from natural concentration levels. This was confirmed by multivariate statistical analysis. The mHQ data showed high level of pollution and toxic effects for $\mathrm{Ni}, \mathrm{Cr}$, significant pollution and toxic effects for $\mathrm{As}$ and $\mathrm{Hg}$, and moderate pollution and toxic effects for $\mathrm{Pb}, \mathrm{Zn}$ and $\mathrm{Cu}$. According to ECI data, the inner gulf is highly polluted and the Poligon Stream is at the forefront in this pollution. Toxic risk has reached significant levels in the vicinity of the ports and near ST 10. Cd created a significant ecological risk in all seasons due to its high toxicity. $\mathrm{Cu}$ and $\mathrm{Pb}$ caused moderate ecological risk in local areas near the port. A moderate potential ecological risk has been identified in all seasons throughout the inner gulf. However, a significant potential ecological risk has emerged in ST 4 in some seasons due to the anthropogenic effects arising from the ports and a significant potential ecological risk has been identified in ST 10 near the mouth of the Poligon Creek due to sewer leakages. The results point to a moderate potential ecological risk and a high level of toxic risk in the inner gulf of İzmir. Directions of currents, rivers and amount of precipitation have an impact on the spatial-seasonal distribution of toxic and ecological risks. In order to ensure the sustainable use of the inner gulf, port activities should be inspected, use of public transportation or metro should be encouraged on transportation lines that are close to the shore and the rehabilitation tasks of rivers, especially the Poligon Stream, should be reviewed.

\section{Acknowledgements}

This study was supported by the Scientific and Technological Research Council of Turkey (TUBITAK) within the scope of project 114Y419. We thank TUBITAK for their support. 


\section{Ethical Approval}

634 Not applicable

635 Consent to Participate

636 Not applicable

637 Consent to Publish

638 All authors approve the publication of the article in your journal

639 Authors Contributions

640 EYÖ, Conceptualization, Funding acquisition, Investigation, Project administration, Writing

641 - original draft

642 Ş.F, Conceptualization, Data curation, Formal analysis, Software, Writing - original draft

643 Visualization

644 S.K, Conceptualization, Formal analysis, Methodology, Resources, Writing - review \&

645 editing

646 HBB, Conceptualization, Funding acquisition, Project administration, Validation, Writing -

647 review \& editing

648 All authors read and approved the final manuscript.

649 Funding

650 This study was supported by the Scientific and Technological Research Council of Turkey

651 (TUBITAK) within the scope of project 114Y419. We thank TUBITAK for their support.

652 Competing interests

653 The authors declare that they have no competing interests

654 Availability of data and materials

655 The datasets used and/or analysed during the current study are available from the

656 corresponding author on reasonable request.

657 The datasets generated during and/or analysed during the current study are available in the

658 [NAME] repository, [PERSISTENT WEB LINK TO DATASETS]

659

660

661 
Ahmed, I., Mostefa, B., Bernard, A., Olivier, R. (2018). Levels and ecological risk assessment of heavy metals in surface sediments of fishing grounds along Algerian coast. Marine Pollution Bulletin 136, 322-333. https://doi.org/10.1016/j.marpolbul.2018.09.029.

Ahamad M.I., Song J., Sun H., Wang X., Mehmood M.S., Sajid M., and Khan A.J. (2020). Contamination level, ecological risk, and source identification of heavy metals in the hyporheic zone of the Weihe River, China. Int. J. Environ. Res. Public Health, 17, 1070. https://doi.org/10.3390/ijerph17031070.

Altın, A., Filiz, Z., Iscen, C.F. (2009). Assessment of seasonal variations of surface water quality characteristics for Porsuk Stream. Environ. Monit. Assess. 158, 5165. https://doi.org/10.1007/s10661-008-0564-3.

Algül F. And Beyhan M. (2020). Concentrations and sources of heavy metals in shallow sediments in Lake Bafa, Turkey. Scientific Reports, 10, 11782. https://doi.org/10.1038/s41598-020-688332.

Alrabie, N. A. et al. (2019). Heavy metals concentrations in stormwater and tilapia fish (Oreochromis niloticus) in Kuala Lumpur holding and storage SMART ponds. Pertanika J. Trop. Agric. Sci. 42, 1, 225-236. ISSN 1511-3701; ESSN: 2231-8542.

Ali, U. et al. (2015). Mass burden and estimated flux of heavy metals in Pakistan coast: sedimentary pollution and eco-toxicological concerns. Environ. Sci. Pollut. Res. 22, 4316. https ://doi.org/10.1007/s1135 6-014-3612-2.

Amin, B., Ismail, A., Arshad, A., Yap, C. K., \& Kamarudin, M. S. (2009). Anthropogenic impacts on heavy metal concentrations in the coastal sediments of Dumai, Indonesia. Environmental Monitoring and Assessment, 148, 291-305. https://doi.org/10.1007/s10661-008-0159-z.

Atalar M., Küçüksezgin F., Duman M., Gönül T. (2013). Heavy metal concentrations in surficial and core sediments from İzmir Bay: an assessment of contamination and comparison against sediment quality benchmarks. Bull Environ Contam Toxicol, 91, 69-75. https ://doi.org/10.1007/s00128-013-1008-5.

Bat L, Özkan E.Y, Öztekin HC. (2015). The contamination status of trace metals in Sinop coast of the Black Sea, Turkey. Caspian Journal of Environmental Sciences (CJES). 13, 1, 1-10. http://aquaticcommons.org/id/eprint/21748.

Bat L. (2017). The contamination status of heavy metals in fish from the Black Sea, Turkey and potential risks to human health. In: Sezgin, M., Bat, L., Ürkmez, D., Arıcı, E., Öztürk, B. (Eds.) Black Sea Marine Environment: The Turkish Shelf. Turkish Marine Research Foundation (TUDAV), Publication No: 46, ISBN- 978-975-8825-38-7, Istanbul, pp. 322-418.

Bat L, Öztekin A, Şahin F, Arıcı E, Özsandıkçı U. (2018). An overview of the Black Sea pollution in Turkey. MedFAR., 1, 67-86.

Bat L, Arıc1 E. (2018). Chapter 5. Heavy metal levels in fish, molluscs, and crustacea from Turkish seas and potential risk of human health. In: Holban AM, Grumezescu AM. (Eds.) Handbook of Food Bioengineering, Volume 13, Food Quality: Balancing Health and Disease. Elsevier, 
Academic Press, ISBN: 978-0-12-811442-1, pp. 159-196. http://dx.doi.org/10.1016/B978-012-811442-1.00005-5.

Bat, L., Özkan, E. Y. (2019). Heavy metal levels in sediment of the Turkish Black Sea Coast. In I. Management Association (Ed.), Oceanography and Coastal Informatics: Breakthroughs in Research and Practice (pp. 86-107). Hershey, PA: IGI Global. http://doi:10.4018/978-1-52257308-1.ch004.

Bat L, Kurt G. (2020). Use of polychaeta species as bioindicator for heavy metal pollution in marine environments. (In): Bayram T, Zayachuk Y, Gupta DK. (Eds.) Environmental Radioactivity in Turkish Environment. Sivas Cumhuriyet Üniversitesi Matbaas1, ISBN 978-605-7902-40-5, pp. 259-281.

Bat L, Arıcı E, Öztekin A. (2021). Threats to quality in the coasts of the Black Sea: heavy metal pollution of seawater, sediment, Macro-Algae and Seagrass. In: Shit P.K., Adhikary P.P., Sengupta D. (eds) Spatial Modeling and Assessment of Environmental Contaminants. Environmental Challenges and Solutions. Springer, Cham. pp. 289-325. https://doi.org/10.1007/978-3-030-63422-3_18.

Beneditto, A. M., Semensato, G. E., Carvalho, C., \& Rezende, C. (2019). Trace metals in two commercial shrimps from southeast Brazil: Baseline records before large port activities in coastal waters. Marine Pollution Bulletin, 146, 667-670. https://doi.org/10.1016/j.marpolbul.2019.07.028.

Beşiktepe, Ş. T., Sayın, E., İlhan, T., \& Tokat, E. (2011). Investigation of İzmir Bay current dynamics with the help of model and observation. 7th Coastal Engineering Symposium, 427-437. Trabzon: TMMOB.

Bastami, K.D.; Bagheri, H.; Kheirabadi, V.; Zaferani, G.G.; Teymori, M.B.; Hamzehpoor, A.; Soltani, F.; Haghparast, S.; Harami, S.R.M.; Ghorghani, N.F.; Ganji S. (2014). Distribution and ecological risk assessment of heavy metals in surface sediments along southeast coast of the Caspian Sea. Marine. Pollution. Bull. 81, 262-267. https://doi.org/10.1016/j.marpolbul.2014.01.029.

Barbieri, M. (2016). The importance of enrichment factor (EF) and geoaccumulation index ( $\left.\mathrm{I}_{\text {geo }}\right)$ to evaluate the soil contamination. Geology \& Geophysics, Scientific Reports, 4, 7152.

Benson, N.U., Adedapo, A.E., Fred-Ahmadu, O.H., Williams, A.B., Udosen, E.D., Ayejuyo, O.O., Olajire, A.A., (2018). New ecological risk indices for evaluating heavy metals contamination in aquatic sediment: A case study of the Gulf of Guinea. Regional Studies in Marine Science 18, 44-56. https://doi.org/10.1016/j.rsma.2018.01.004.

Brady, J.P., Ayoko, G.A., Martens, W.N., Goonetilleke, A. (2015). Development of a hybrid pollution index for heavy metals in marine and estuarine sediments. Environ. Monit. Assess. 187, 306. https://doi.org/10.1007/s10661-015-4563-x

Chen, Y., Liu, Q., Xu, M., \& Wang, Z. (2020). Inter-annual variability of heavy metals pollution in surface sediments of Jiangsu coastal region, China: Case study of the Dafeng Port. Marine Pollution Bulletin, https://doi.org/110720. 10.1016/j.marpolbul.2019.110720.

De Master, D.J., 1981. The supply and accumulation of silica in the marine environment. Geochimica et Cosmochimica Acta 45, 1715-1732. https://doi.org/10.1016/0016-7037(81)90006-5. 
ESRI. (2021). https://desktop.arcgis.com/en/arcmap/10.3/tools/ 3d-analyst-toolbox/how-krigingworks.htm

Fural, Ş., Kükrer, S., Cürebal, İ. (2020). Geographical information systems based ecological risk analysis of metal accumulation in sediments of İkizcetepeler Dam Lake (Turkey). Ecological Indicators, 119. https://doi.org/10.1016/j.ecolind.2020.106784.

Fural, Ş., Kükrer, S., Cürebal, İ., \& Aykır, D. (2021). Spatial distribution, environmental risk assessment, and source identification of potentially toxic metals in Atikhisar dam, Turkey. Environmental Monitoring and Assessment. 193, https://doi.org/10.1007/s10661-021-090626.

Feng H, Jiang H, Gao W, Weinstein M P, Zhang Q, Zhang W, Yu L, Yuan D and Tau J. (2011). Metal contamination in sediments of the western Bohai Bay and adjacent estuaries, China. Journal of Environmental Management, 92, 1185-97. https://doi.org/10.1016/j.jenvman.2010.11.020.

Gao, L.;Wang, Z.; Shan, J.; Chen, J.; Tang, C.; Yi, M.; Zhao, X. (2016). Distribution characteristics and sources of trace metals in sediment cores from a trans-boundary watercourse: An example from the Shima River, Pearl River Delta. Ecotoxicol. Environ. Saf. 134, 186-195. https://doi.org/10.1016/j.ecoenv.2016.08.020.

Gaudette, H.E., Flight, W.R., Toner, L., Folger, D.W. (1974). An inexpensive titration method for the determination of organic carbon in recent sediments. Journal of Sedimentary Research 44, 249-253. https://doi.org/10.1306/74D729D7-2B21-11D7-8648000102C1865D.

Gülsever, G., Arslan, Ö.Ç. (2019). Current status of heavy metal pollution in İzmir inner bay sediments. 2nd International Agriculture, Environment and Health Congress Full Text Abstract Book, 1769-1776.

Hakanson, L. (1980). An ecological risk index for aquatic pollution control: A sedimentological approach. Water Research, 8, 975-1001.

Hasan A.B., Kabir S., Reza A.H.M., Zaman M.N., Ahsan A., Rashid M. (2013). Enrichment factor and geo-accumulation index of trace metals in sediments of the ship breaking area of Sitakund Upazilla (Bhatiary-Kumira), Chittagong, Bangladesh. Journal of Geochemical Exploration, $125,130-137$.

Kaya, H., Erginal, G., Çakır, Ç., Gazioğlu, C., Erginal, A. (2017). Ecological risk evaluation of sediment core samples, Lake Tortum (Erzurum, NE Turkey) using environmental indices. International Journal of Environment and Geoinformatics, 4, 227-239. https://doi.org/10.30897/ijegeo.348826.

Kontaş, A., Kucuksezgin, F., Altay, O., Uluturhan, E., 2004. Monitoring of eutrophication and nutrient limitation in the İzmir Bay (Turkey) before and after Wastewater Treatment Plant. Environment International, 29, 1057-1062. https://doi.org/10.1016/S0160-4120(03)00098-9

Kükrer, S., Erginal, A. E., Kılıç, Ş., Bay, Ö., Akarsu, T., \& Öztura, E. (2020). Ecological risk assesment of surface sediments of Çardak Lagoon along a human disturbance gradient. Environ Monit Asses, 192. https://doi.org/10.1007/s10661-020-08336-9.

Li, X., Liu, L., Wang, Y., Luo, G., Chen, X., Yang, X., et al. (2012). Integrated assessment of heavy metal contamination in sediments from a coastal industrial basin, NE China. PLoS ONE, 7(6), 1-10. https://doi.org/10.1371/journal.pone.0039690. 
Li, Y., Qu, X., Zhang, M., Peng, W., Yu, Y., Gao, B., 2018. Anthropogenic Impact and Ecological Risk Assessment of Thallium and Cobalt in Poyang Lake Using the Geochemical Baseline. Water 10, 1703. https://doi.org/10.3390/w10111703.

Liu, J. et al. (2017). Occurrence and risk assessment of heavy metals in sediments of the Xiangiiang River, China. Environ. Sci. Pollut. Res.Int. 24, 2711. https://doi.org/10.1007/s11356-0168044-8.

Looi L.J., Aris A.Z., Yusoff F., Mohd N and Haris I.H. (2019). Application of enrichment factor, geoaccumulation index, and ecological risk index in assessing the elemental pollution status of surface sediments. Environ Geochem Health, 41,27-42 https://doi.org/10.1007/s10653-0180149-1.

Macdonald, D.D., Carr, R.S., Calder, F.D. (1997). Development and evaluation of sediment quality guidelines for Florida coastal waters. Oceanographic Literature Review, 6, 638.

MacDonald, D.D., Ingersoll, C.G., Berger, T.A. (2000). Development and Evaluation of ConsensusBased Sediment Quality Guidelines for Freshwater Ecosystems. Arch. Environ. Contam. Toxicol. 39, 20-31. https://doi.org/10.1007/s002440010075.

Martin, D.F., 1972. Marine Chemistry: Theory and Applications, First U.S. Edition. ed. Marcel Dekker Inc, New York, NY.

MGM, (2021). (General Directorate of Meteorology) https://izmir.mgm.gov.tr/.

MTA, (2021). http:// earth sciences.mta.gov.tr/mainpage.aspx.

Niu, Y. et al. (2015). Spatial evaluation of heavy metals concentrations in the surface sediment of Taihu Lake. Int. J. Environ. Res. Public Health, 12, 15028-15039.

Özkan, E.Y. (2012). "A new assessment of heavy metal contaminations in an Europhicated Bay (Inner İzmir Bay, Turkey)” Turkish Journal of Fisheries and Aquatic Sciences, 12, 135-147.

Özkan E.Y. and Büyükışık B. (2012). "Geochemical and statistical approach for assessing heavy metal accumulation in the Southern Black Sea Sediments" Ecology, 21, 11-24.

Jahan, S., \& Strezov, V. (2018). Comparison of pollution indices for the assessment of heavy metals in the sediments of seaports of NSW, Australia. Marine Pollution Bulletin, 128, 298-306. https://doi.org/10.1016/j.marpolbul.2018.01.036.

Jeong, H., Choi, Y. J., Lim, J., Shim, J. W., Kim, Y. O., \& Ra, K. (2020). Characterization of the contribution of road deposited sediments to the contamination of the close marine environment with trace metals: Case of the port city of Busan (South Korea). Marine Pollution Bulletin, 161, https://doi.org/111717. 10.1016/j.marpolbul.2020.111717.

Ji, K.; Kim, J.; Lee, M.; Park, S.; Kwon, H.J.; Cheong, H.K.; Jang, J.Y.; Kim, D.S.; Yu, S.; Kim, Y.W.; Lee K.W.; Yang S.O; (2013). Assessment of exposure to heavy metals and health risks among residents near abandoned metal mines in Goseong, Korea. Environ. Pollut. 178, 322328. https://doi.org/10.1016/j.envpol.2013.03.031.

Merhaby, D., Ouddane, B., Net, S., \& Halvani, J. (2018). Assessment of trace metals contamination in surficial sediments along Lebanese Coastal Zone. Marine Pollution Bulletin, 113, 881-890. https://doi.org/10.1016/j.marpolbul.2018.06.031. 
Muhammad, S.; Shah, M.T.; Khan, S. (2011). Heavy metal concentrations in soil and wild plants growing around $\mathrm{Pb}-\mathrm{Zn}$ sulfide terrain in the Kohistan region, northern Pakistan. Microchem. J. 99, 67-75. https://doi.org/10.1016/j.microc.2011.03.012.

Müller, G. (1996). Index of geoaccumulation in sediments of the Rhine River. Geo Journal, 2, 108 118.

Nowrouzi M. and Pourkhabbaz A. (2014). Application of geoaccumulation index and enrichment factor for assessing metal contamination in the sediments of Hara Biosphere Reserve, Iran. Chemical Speciation and Bioavailability, 26, 99-105, https://doi.org/10.3184/095422914X13951584546986.

Oliveira, T. S., Xavier, D., Santos, L. D., França, E. J., Sanders, C. J., Passos, T. U., \& Barcellos, R. L. (2020). Geochemical background indicators within a tropical estuarine system influenced by a port-industrial complex. Marine Pollution Bulletin, 161, https://doi.org/111794. 10.1016/j.marpolbul.2020.111794.

Özkan, E.Y., Kocatas, A., Büyükışık, B., (2008). Nutrient dynamics between sediment and overlying water in the inner part of İzmir Bay, Eastern Aegean. Environ. Monit. Assess. 143, 313-325. https://doi.org/10.1007/s10661-007-9984-8.

Özkan, E. Y., Büyükışık, H. B., Kontaş, A., \& Türkdoğan , M. (2017). A survey of metal concentrations in marine sediment cores in the vicinity of an old mercury-mining area in Karaburun, Aegean Sea. Environ. Sci. Pollut. Res., 24, 13823-13836.

Panagos, A., Papadopoulos, N., Alexandropoulou, S., Synetos, S.,\& Varnavas, S. (1989). Geochemical study of sediments from deposits. Marine Geology,110,93-114. doi:10.1016/00253227(93)90108-8.

Phillips DJH, Rainbow P.S. (1993) Biomonitoring of aquatic trace contaminants. London Chapman and Hall.

Palas, S., (2020) Investigation of heavy metal accumulation in Late Quaternary-Contemporary surface sediments of Aliağa Bay, M.T.A. Natural Resources and Economy Bulletin, 29, 29-48.

Roberts, D.A., Birchenough, S.N., Lewis, C., Sanders, M.B., Bolam, T., Sheahan, D. (2013). Ocean acidification increases the toxicity of contaminated sediments. Global Change Biology 19, 340-351. https://doi.org/10.1111/gcb.12048.

Rainbow PS (1992) The significance of accumulated heavy metal concentrations in marine organisms. In: Miskiewicz AG (ed) Assessment of the distribution, impacts and bioaccumulation of contaminants in aquatic environments, Proceedings of a bioaccumulation Workshop. Water Board and Australian Marine Science Association Inc., Sydney.

Rumisha, C., Elskens, M., Leermakers, M., \& Kochzius, M. (2012). Trace metal pollution and its influence on the community structure of soft bottom molluscs in intertidal areas of the Dar es Salaam coast, Tanzania. Marine Pollution Bulletin, 521-531. https://doi.org/10.1016/j.marpolbul.2011.12.025.

Rodríguez-Espinosa, P.F., Shruti, V.C., Jonathan, M.P., Martinez-Tavera, E., 2018. Metal concentrations and their potential ecological risks in fluvial sediments of Atoyac River basin, 
Central Mexico: Volcanic and anthropogenic influences. Ecotoxicology and Environmental Safety 148, 1020-1033. https://doi.org/10.1016/j.ecoenv.2017.11.068.

Strickland, J., Parsons, T., 1972. A Practical Handbook of Seawater Analysis.

Schiff, K.C. and Weisberg, S.B. (1999) Iron as a reference element for determining trace metal enrichment in Southern California coast shelf sediments. Mar. Environ. Res., 48, 161-176.

Siddiquee, N.A., Ahmed, M.K., Quddus, M.M.A., Parween, S., Islam, M.H. (2006). Trace metal concentration in sediments of Chittagong ship breaking area. The Journal of Noami. 23, 2330.

Singovszka, E. and Balintova M. (2019). Enrichment Factor and Geo-Accumulation Index of Trace Metals in Sediments in the River Hornad, Slovakia. IOP Conf. Series: Earth and Environmental Science 222, https://doi.org/10.1088/1755-1315/222/1/012023.

Sunlu, F.S., Sunlu, U., Büyükış1k, B., Kükrer, S., Uncumusaoglu, A., 2012. Nutrient and chlorophyll a trends after wastewater treatment plant in İzmir Bay (Eastearn Aegean Sea). Journal of Animal and Veterinary Advances 11, 113-123. https://doi.org/10.3923/javaa.2012.113.123.

Sutherland, R.A., 2000. Bed sediment-associated trace metals in an urban stream, Oahu, Hawaii. Environmental Geology 39, 611-627. https://doi.org/10.1007/s002540050473.

Sun, Z.; Mou, X.; Tong, C.; Wang, C.; Xie, Z.; Song, H.; Sun, W.; Lv, Y. (2015). Spatial variations and bioaccumulation of heavy metals in intertidal zone of the Yellow River estuary, China. Catena, 126, 43-52. http://dx.doi.org/10.1016/j.catena.2014.10.037.

Tang, W., Shan, B., Zhang, H., Zhang, W., Zhao, Y., Ding, Y., et al. (2014). Heavy metal contamination in the surface sediments of representative limnetic ecosystems in eastern China. Scientific Reports, 4, 1-7. https://doi.org/10.1038/srep07152.

Tunca, E., Aydın, M. \& Şahin, Ü.A. (2018). An ecological risk investigation of marine sediment from the northern Mediterranean coasts (Aegean Sea) using multiple methods of pollution determination. Environ. Sci. Pollut. Res. 25, 7487-7503.https://doi.org/10.1007/s11356-0170984-0.

Varol, M. \& Şen, B. (2012). Assessment of nutrient and heavy metal contamination in surface water and sediments of the upper Tigris River, Turkey. Catena, 92, 1-10. https://doi.org/10.1016/j.catena.2011.11.011.

Viard, B., Pihan, F., Promeyrat, S., \& Pihan, J.-C. (2004). Integrated assessment of heavy metal (Pb, $\mathrm{Zn}, \mathrm{Cd}$ ) highway pollution: bioaccumulation in soil, Graminaceae and land snails. Chemosphere, 55, 1349-1359.

Varnavas, S. P. (1989). Metal Pollution of the Kalloni Bay,Lesvos Greece. Proceedings of the conference“ Environmen-tal Science and Technology”, Lesvos, Greece, 211-220.

Williams J.A. and Antoine J. (2020). Evaluation of the elemental pollution status of Jamaican surface sediments using enrichment factor, geoaccumulation index, ecological risk and potential $\begin{array}{lllll}\text { ecological risk index. Marine Pollution } & 157 .\end{array}$ https://doi.org/10.1016/j.marpolbul.2020.111288. 
Xiao, R.; Bai, J.; Lu, Q.; Zhao, Q.; Gao, Z.; Wen, X.; Liu, X. (2015). Fractionation, transfer, and ecological risks of heavy metals in riparian and ditch wetlands across a 100-year chronosequence of reclamation in an estuary of China. The Science of the Total Environment. 517, 66-75. https://doi.org/10.1016/j.scitotenv.2015.02.052.

$\mathrm{Xu}, \mathrm{F}$. et al. (2017). Assessment of heavy metal contamination in urban river sediments in the Jiaozhou Bay catchment, Qingdao, China. Catena, 150, 9-16. https://doi.org/0.1016/j.catena.2016.11.004.

Yang, J. et al. (2014). Sediment quality assessment for heavy metal contamination in the Dongzhai Harbor (Hainan Island, China) with pollution indice approach. The Open Chemical Engineering Journal, 8, 32-37.

Zhang, G., Bai, J., Zhao, Q., \& et al. (2016). Heavy metals in wetland soils along a wetland-forming chronose quence in the Yellow River Delta of China: Levels, sources and toxic risks. Ecological Indicators. 69, 331-339. https://doi.org/10.1016/j.ecolind.2016.04.042. 